\title{
RENEWABLE ENERGY SOURCES IN THE LUBUSZ VOIVODSHIP (POLAND). THE PRESENT CONDITIONS AND PERSPECTIVES FOR DEVELOPMENT
}

\author{
Andrzej ŁĄCZAK ${ }^{2}$, Anna BAZAN-KRZYWOSZAŃSKA3, \\ Maria MRÓWCZYŃSKA ${ }^{3}$, Marta SKIBA ${ }^{1}$ \\ University of Zielona Góra, Poland
}

\begin{abstract}
The article presents the present situation in terms of energy production from renewable energy sources and perspectives for development, based on research on the existing resources and possibilities of using them. The Lubusz Voivodship is not an important energy producer in Poland. In terms of the amount of energy produced it comes twelfth out of sixteen voivodships. The annual energy production from renewable energy sources is $290,9 \mathrm{GWh}$, which is $11.6 \%$ of the total energy produced. At the end of 2014 there were 73 licensed installations producing electrical energy from renewable energy sources in the Lubusz Voivodship with a total capacity of $189 \mathrm{MW}$. The largest amount of energy is produced by a pumped storage power plant $(91,3 \mathrm{MW})$. The total capacity of the licensed installations using RES in the Lubusz Voivodship rose from $103 \mathrm{MW}$ in 2007 to about $189 \mathrm{MW}$ in 2014. Research on the existing resources indicates that it is possible to develop RES. Preparations are under way to build 66 new wind farms with a total capacity of 1834 MW [35], 89 photovoltaic power plants with a total capacity of $468 \mathrm{MW}, 21$ water power
\end{abstract}

\footnotetext{
${ }^{1}$ Corresponding author: University of Zielona Góra, Faculty of Civil Engineering, Architecture and Environmental Engineering, Z. Szafrana s 1, 65-516 Zielona Góra, Poland, e-mail: m.skiba@ib.uz.zgora.pl, tel.+48683282309

2 The Branch Faculty of the University of Zielona Góra in Sulechów Poland, e-mail: a.laczak@wzs.uz.zgora.pl

3 University of Zielona Góra, Faculty of Civil Engineering, Architecture and Environmental, Z. Szafrana s 1, 65-516 Zielona Góra, Poland
} 
plants with a total capacity of about $60 \mathrm{MW}, 54$ biogas power plants with a total expected capacity of about $67 \mathrm{MW}$. The total capacity of the RES installations that are planned to be built by 2023 will be $2469 \mathrm{MW}$. Therefore, in the coming years the installed capacity of RES installations will increase 13 times in the Lubusz Voivodship. There are still no plans to use the energy of deep geothermal waters due to low profitability.

Keywords: renewable energy sources, Lubusz Voivodship

\section{INTRODUCTION}

The world's economic development brings about an increasing demand for electrical and thermal energy. The shrinking conventional energy sources and increasing environmental pollution result in the necessity to search for new, renewable energy sources. The EU regulations [4,2] stipulate that the participation of energy from renewable energy sources in the final gross energy

\section{Energy obtained from RES in Poland in 2013 according to energy carriers}

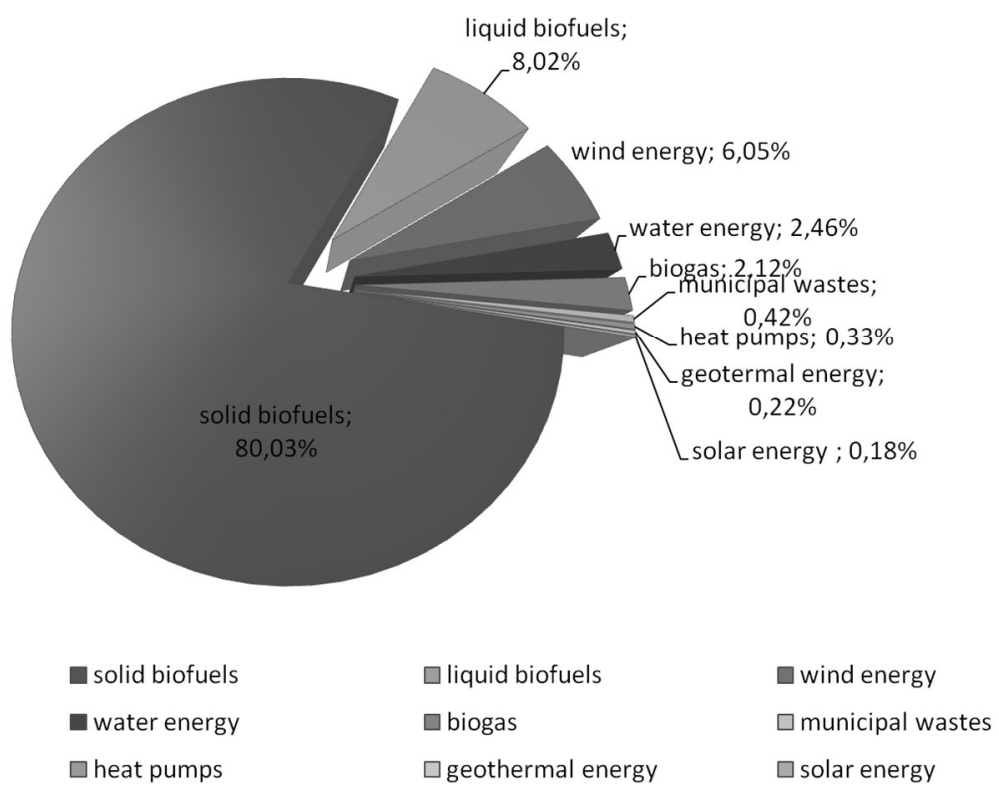

Fig. 1. Energy from RES in Poland, according to energy carriers in 2013. (Source: prepared by the author) 
consumption in the EU should be at least $20 \%$ in the year 2020. Each of the member states has a different goal to achieve. The goal for Poland is to increase the participation of energy from renewable energy sources in the final gross energy consumption from 7,2\% in 2005 to $15 \%$ in 2020 [4]. By the year 2013 the participation of renewable energy in the final gross energy consumption had increased in Poland by $4,1 \%$ and was $11,3 \%$ [6]. $80 \%$ of renewable energy in Poland comes from solid biofuels. Liquid biofuels provide 8,2\% of energy, wind energy $6,05 \%$, solar energy $2,46 \%$, and biogas $2,12 \%$. Energy from other energy sources amounts in total to slightly over 1\%. (Fig. 1) [37].

The most important role in the production of electrical energy from renewable energy sources is played by solid biofuels, whose participation in energy production amounts to $46,43 \%$, also wind $(35,15 \%)$ and water $(14,29 \%)$. Bioliquids and municipal wastes are much less important (Fig.2). The participation of renewable energy carriers in the production of thermal energy is even less varied. Over $97 \%$ of the thermal energy produced comes from solid biofuels [37].

\section{The participation of Renewable Energy carriers in electrical energy production in 2013}

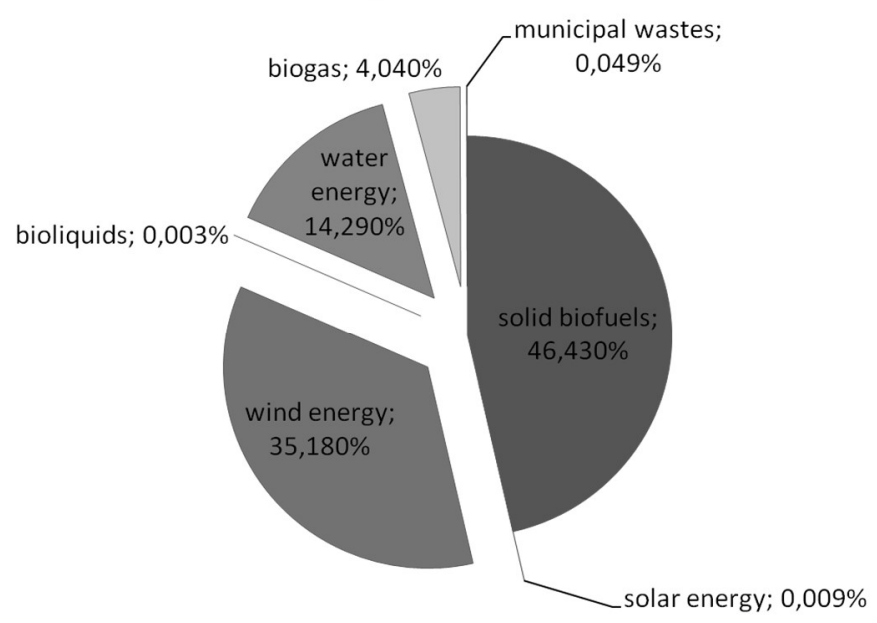

$\square$ solid biofuels $\square$ solar energy $\square$ wind energy $\square$ bioliquids $\square$ water energy $\square$ biogas $\square$ municipal wastes

Fig. 2. The participation of renewable energy carriers in electrical energy production in 2013. (Source: prepared by the author) 


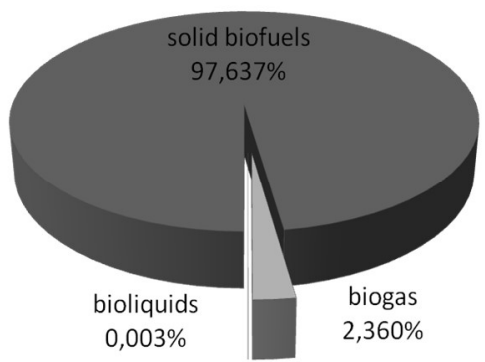

Fig. 3. The participation of renewable energy carriers in thermal energy production in 2013. (Source: prepared by the author)

The energetic potential of particular regions of Poland is varied and depends on resources and natural conditions, but also on infrastructure and the economic potential. The Lubusz Voivodship is regarded as a region with quite a low potential for renewable energy. One of the fastest developing methods of renewable energy production in Poland, which has a considerable potential, is the use of wind energy. The best conditions for the development of wind energy production are in the West Pomeranian Voivodship (a potential of $14 \mathrm{GW}$ ) and the Pomeranian Voivodship, the Wielkopolska Voivodship, the KuyavianPomeranian Voivodship and the Podlaskie Voivodship [20]. Because of Poland's geographical location solar energy plays an insignificant role in our country. The total potential for solar energy production is over $19000 \mathrm{TJ}$ and it requires the installation of about 14,7 million $\mathrm{m}^{2}$ of solar collectors. The best conditions for the development of solar energy production are in the Masovian Voivodship, the Silesian Voivodship, the Małopolska Voivodship and the Wielkopolska Voivodship. The Lubusz Voivodship as well as the Opole Voivodship, the Świętokrzyskie Voivodship and the Podlasie Voivodship are regarded as regions with the lowest potential $[20,17]$. The development of energy production using biomass depends on the area of long-term plantations of energetic plants and straw. The largest biomass resources are in the Wielkopolska Voivodship and they are estimated at $216 \mathrm{MW}$, as well as in the Warmian-Masurian Voivodship - 106 MW and the Masovian Voivodship - 103 MW, but the Lubusz Voivodship is regarded as one of the regions with the lowest potential $[20,24]$. Poland has large geothermal resources, but their development depends on location, accessibility to heat networks and receivers located near the source. For this 
reason a large number of resources cannot be rationally used. Water energy production can play an important role in the development of renewable energy sources in Poland. In favourable administrative, legal and political conditions power produced by water power plants may amount to $1176 \mathrm{MW}$ by the year 2020 , and the average production per year $-3100 \mathrm{GWh}$.

\section{CHARACTERISTICS OF THE LUBUSZ VOIVODSHIP}

The Lubusz Voivodship is located in the western part of Poland and it borders on the German land of Brandemburg and partially Sachsen. It is one of the smallest regions of Poland with an area of $13988 \mathrm{~km}^{2}$, and a population of 1.02 million [27]. The climate in the voivodship is moderate with considerable differences in temperatures between the north and the south of the region. In summer the south of the voivodship is much warmer, and the north is warmer in winter. However, differences between average annual temperatures in the main towns - Gorzów Wlkp. and Zielona Góra are small and amount to $9,1^{\circ} \mathrm{C}$ for Gorzów Wlkp., and $8,8^{\circ} \mathrm{C}$ for Zielona Góra [27]. The average wind speed is $2,7 \mathrm{~m} / \mathrm{s}$ in Gorzów Wlkp., and 3,0 m/s in Zielona Góra. In 2013 the average insolation was 1817 hours in the north of the voivodship, and 1491 hours in the south, at the same time the north of the region was cloudier. There is considerable forestation in the voivodship, about $50 \%$ of the area is covered with forest. The terrain is quite flat without large hills. The highest hill near Żary is 226,9 above sea level and the lowest point near Kostrzyń on the Oder River is 10 above sea level $[5,7]$.

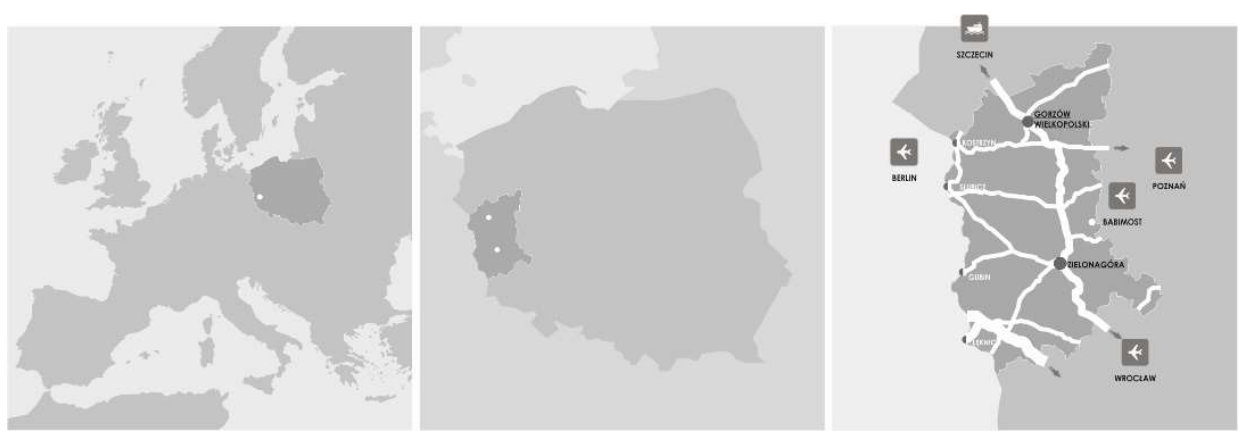

Fig. 4. Poland in Europe, the Lubusz Voivodship in Poland, the Lubusz Voivodship with Gorzów Wielkopolski and Zielona Góra (Source: prepared by the author)

The voivodship is one of the least industrialized regions, which means that energy consumption is among the lowest in the country. There is a smaller demand for energy only in the Podlaskie Voivodship. This is one of the reasons why pollution emission from industrial plants especially unfriendly to the environment is relatively small. The emission of dust pollution is 1.1 thousand tonnes compare 
with $49,5 * 10^{3} \mathrm{t}$ in the country, and the emission of gas pollution is $2009,5 * 10^{3} \mathrm{t}$ compared with $217492 * 10^{3}$ tonnes in the country, which is only $0,9 \%$ [33]. The consumption of gas from the mains is about $350^{*} 10^{6} \mathrm{~m}^{3}$ per year, which is $\pm 5 \%$, depending on the weather. However, the demand for electricity is growing systematically in the voivodship, the increase rate is about $1 \%$ per year, and $3347 \mathrm{GWh}$ were consumed in 2014 [34]. The peak capacity is on a constant level of $700 \mathrm{MW}$ [29]. Electrical energy production in 2014 was 2504 GWh (Fig. 5), which means that there was a lack of $844 \mathrm{GWh}$. This means that the voivodship is not self-dependent in terms of energy.

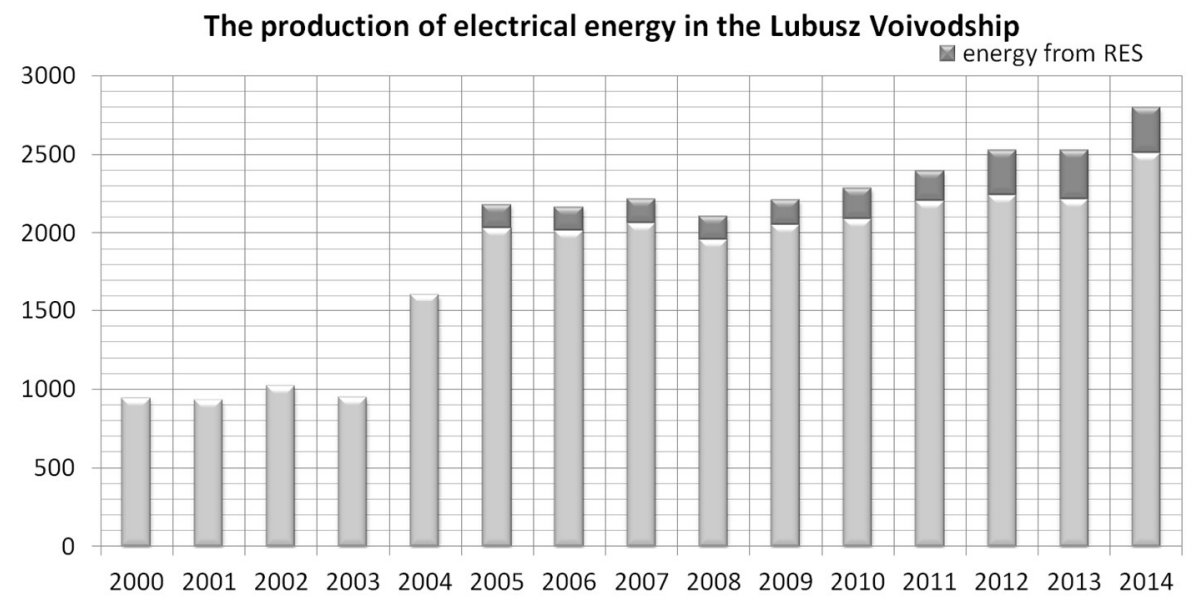

Fig. 5. Production of electrical energy in the Lubusz Voivodship, including renewable energy sources [GWh] (Source: prepared by the author, based on www.stat.gov.pl, access date 10 November 2015)

\subsection{Production of energy from renewable energy sources in the Lubusz Voivodship compared with the whole country}

First place in terms of production of energy from renewable energy sources in Poland belongs to the Western Pomeranian Voivodship, i.e. a region with good conditions for the development of wind energy production. The voivodship produces over $3089 \mathrm{GWh}$ of energy [12]. Second place in terms of renewable energy production belongs to the Świętokrzyskie Voivodship. The Połaniec power plant using biomass, with its power unit with a capacity of over $200 \mathrm{MW}$ contributes to high energy production in the region. Third place belongs to the Kuyavian-Pomeranian Voivodship, which produces over $2212 \mathrm{GWh}$ of electrical energy [11]. High energy production in the region is possible because of a high potential for wind energy [25]. The Lubusz Voivodship is not a significant electrical energy producer in Poland and comes twelfth in terms of energy 
production among 16 voivodships. In comparison with the country's average a considerable percentage of energy $(11,6 \%)$ is produced from renewable energy sources, which amounts to $290.9 \mathrm{GWH}$ per year (Table 1). In comparison with the year 2013 production of energy from renewable energy sources has fallen in the Lubusz Voivodship by $21.2 \mathrm{GWh}$.

Table 1. Production of energy from renewable energy sources in particular voivodships in the years 2005 - 2014 (Source: prepared by the author, based on the Local Data

Bank)

\begin{tabular}{|c|c|c|c|c|c|c|c|c|c|c|}
\hline \multirow[t]{2}{*}{ Territorial unit } & 2005 & 2006 & 2007 & 2008 & 2009 & 2010 & 2011 & 2012 & 2013 & 2014 \\
\hline & GWh & GWh & GWh & GWh & GWh & GWh & GWh & GWh & GWh & GWh \\
\hline POLAND & 3847,3 & 4291,2 & 5429,3 & 6606,0 & 8678,7 & 10888,8 & 13136,9 & 16878,9 & 17066,6 & 19841,2 \\
\hline ŁÓDŹ & 58,0 & 65,3 & 94,7 & 141,0 & 224,2 & 429,8 & 603,0 & 1165,1 & 953,0 & 927,2 \\
\hline MASOVIAN & 181,9 & 174,1 & 314,6 & 555,6 & 720,9 & 1010,6 & 1194,1 & 1698,5 & 1800,1 & 1982,7 \\
\hline MAŁOPOLSKA & 480,4 & 489,9 & 602,0 & 597,1 & 692,5 & 783,8 & 868,6 & 886,3 & 480,7 & 590,8 \\
\hline SILESIAN & 101,8 & 241,4 & 331,8 & 464,3 & 1090,6 & 1519,7 & 1678,1 & 2223,7 & 1548,9 & 1761,5 \\
\hline $\begin{array}{l}\text { LUBLIN } \\
\end{array}$ & 9,1 & 16,9 & 20,7 & 35,8 & 16,7 & 14,5 & 18,3 & 31,8 & 47,7 & 55,1 \\
\hline PODKARPACKIE & 172,3 & 177,3 & 177,8 & 211,5 & 267,2 & 315,7 & 319,7 & 342,5 & 394,6 & 459,8 \\
\hline PODLASKIE & 8,3 & 8,8 & 9,9 & 60,3 & 217,5 & 236,3 & 388,9 & 435,3 & 600,0 & 654,7 \\
\hline ŚWIĘTOKRZYSKIE & 326,8 & 375,7 & 396,4 & 611,2 & 758,1 & 821,6 & 883,9 & 1265,7 & 1745,2 & 2416,4 \\
\hline LUBUSZ & 151,8 & 150,5 & 156,4 & 150,5 & 163,7 & 197,1 & 191,2 & 287,5 & 312,1 & 290,9 \\
\hline WIELKOPOLSKIE & 90,4 & 136,0 & 314,9 & $\begin{array}{l}513,8 \\
\end{array}$ & 586,4 & 927,6 & 1009,5 & 1319,3 & 1280,6 & 1489,9 \\
\hline $\begin{array}{l}\text { WESTERN- } \\
\text { POMERANIAN }\end{array}$ & 305,5 & 413,2 & 551,0 & 685,7 & 812,3 & 697,6 & 1451,7 & 2349,3 & 2654,6 & 3089,7 \\
\hline LOWER-SILESIAN & 207,2 & 207,5 & 257,4 & 272,0 & 446,7 & 658,9 & 703,5 & 897,0 & 763,1 & 1055,9 \\
\hline OPOLE & 142,0 & 206,9 & 248,8 & 255,2 & 286,8 & 269,6 & 308,8 & 340,6 & 444,2 & 558,3 \\
\hline $\begin{array}{l}\text { KUYAVIAN- } \\
\text { POMERANIAN }\end{array}$ & 1197,9 & 1178,7 & 1362,6 & 1269,2 & 1528,1 & 2098,2 & 2063,3 & 1865,8 & 2148,1 & 2212,6 \\
\hline POMERANIAN & 364,5 & 392,9 & 515,9 & 717,4 & 724,4 & 770,1 & 1002,3 & 1215,8 & 1343,8 & 1550,0 \\
\hline $\begin{array}{l}\text { WARMIA- } \\
\text { MASURIAN } \\
\end{array}$ & 49,4 & 56,0 & 74,4 & 65,4 & 142,5 & 137,5 & 452,1 & 554,8 & 549,8 & 746,0 \\
\hline
\end{tabular}

In general on 31 December 2014 in the Lubusz Voivodship there were 73 licensed electrical energy production units using RES (Table 2) with a total capacity of $189 \mathrm{MW}$. The most power was produced by a pumped storage power plant $(91,3$ $\mathrm{MW})$ and the least by landfill biogas $(0,7 \mathrm{MW})$. The total power of the licensed installations using RES in the Lubusz Voivodship increased from $103 \mathrm{MW}$ in 2007 to about $189 \mathrm{MW}$ in 2014 [33]. 
Table 2. A list of licensed RES installations in Poland and in the Lubusz Voivodship (Source: prepared by the author, based on www.ure.gov.pl, as of 31 December 2014)

\begin{tabular}{|c|c|c|c|c|c|c|}
\hline \multirow[t]{3}{*}{ No.- } & \multirow{3}{*}{$\begin{array}{l}\text { Type of } \\
\text { installation }\end{array}$} & \multicolumn{2}{|c|}{ Poland } & \multicolumn{3}{|c|}{ Lubusz Voivodship } \\
\hline & & $\begin{array}{c}\text { Number of } \\
\text { Installations }\end{array}$ & $\begin{array}{l}\text { Capacity of } \\
\text { installations }\end{array}$ & $\begin{array}{c}\text { Number of } \\
\text { installations }\end{array}$ & $\begin{array}{l}\text { Capacity of } \\
\text { installations }\end{array}$ & $\begin{array}{c}\text { Energy } \\
\text { participation }\end{array}$ \\
\hline & & [items] & [MW] & [items] & {$[\mathbf{M W}]$} & [\%] \\
\hline 1 & $\begin{array}{l}\text { biogas power } \\
\text { plants }\end{array}$ & 254 & 188,549 & 7 & 3,911 & 2,07 \\
\hline 2 & $\begin{array}{l}\text { biomass power } \\
\text { plants }\end{array}$ & 36 & 1008,244 & 1 & 1,800 & 0,18 \\
\hline 3 & $\begin{array}{l}\text { geothermal } \\
\text { power plants }\end{array}$ & 0 & 0,000 & 0 & 0,000 & 0,00 \\
\hline 4 & $\begin{array}{l}\text { solar power } \\
\text { plants }\end{array}$ & 119 & 21,003 & 3 & 1,549 & 7,38 \\
\hline 5 & $\begin{array}{l}\text { wind power } \\
\text { plants }\end{array}$ & 931 & 3833,831 & 8 & 63,000 & 1,64 \\
\hline 7 & $\begin{array}{l}\text { water power } \\
\text { plants }\end{array}$ & 756 & 977.006 & 54 & 118,954 & 12,18 \\
\hline 8 & $\begin{array}{l}\text { co-incineration } \\
\text { power plants* }\end{array}$ & 44 & $0,000 *$ & 0 & 0,000 & 0,00 \\
\hline \multicolumn{2}{|c|}{ Total: } & 2140 & 6028,633 & 73 & 189,214 & 3,14 \\
\hline
\end{tabular}

Water energy is used in the Lubusz Voivodship to a higher extent than elsewhere in Poland. The participation of the installed generation capacity of the water power plants in the Lubusz Voivodship amounts to $12,18 \%$ of the installed generation capacity of all water power plants in the country [37]. The installed generation capacity of wind power plants is also increasing systematically. In the region the participation of the installed generation capacity of wind power plants exceeds $33 \%$ of all operating power plants. However, their participation in the country's electrical energy production is merely $1,64 \%$. The structure of the use of renewable energy sources is different in the Lubusz Region from that in the other parts of the country. In Poland wind power plants have the greatest installed generation capacity $(63,59 \%)$, then biomass power plants $(16,72 \%)$ and water power plants $(16,20 \%)$. In the Lubusz Voivodship water power plants have the greatest installed generation capacity $(62,86 \%)$, wind power plants $(33,29)$ and biogas power plants $(2,06 \%)$.

The high participation of water energy is achieved in the voivodship because of the pumped storage power plant in Dychów, which has an installed generation capacity of 91,3 MW. In the voivodship there are relatively many small run-ofthe-river power plants. Most of them are small power plants with an installed generation capacity of $0,3 \mathrm{MW}$ up to $1 \mathrm{MW}$. Table 3 includes detailed numbers and the generation capacity obtained from RES in the voivodship. 
Table 3. The number and power generation capacity obtained from RES in the Lubusz Voivodship (Source: prepared by the author, based on: www.lubuskie.pl/news/16806/16/o-nowej-ustwie-OZE, access date:27 March 2015)

\begin{tabular}{lcc}
\hline \multicolumn{1}{c}{ Type of installation } & $\begin{array}{c}\text { Number of } \\
\text { installations }\end{array}$ & $\begin{array}{c}\text { Power } \\
{[\mathbf{M W}]}\end{array}$ \\
\hline Pumped storage power plant & 1 & 91.3 \\
\hline Wind power plants on land & 8 & 63.0 \\
\hline Run-of-the-river water power plant up to 5 MW & 8 & 13.9 \\
\hline Run-of-the-river water power plant up to 1 MW & 15 & 12.5 \\
\hline Agricultural biogas power plants & 3 & 2.4 \\
\hline $\begin{array}{l}\text { Power plants using biomass from forest, agricultural and garden } \\
\text { wastes }\end{array}$ & 1 & 1.8 \\
\hline Solar power plants & 3 & 1.5 \\
\hline Run-of-the-river water power plant up to 0,3 MW & 30 & 1.2 \\
\hline Power plants using biogas from water treatment plants & 2 & 0.8 \\
\hline Power plants using landfill gas & 2 & 0.7 \\
\hline
\end{tabular}

Installations producing thermal energy from RES are much more difficult to analyse because most of them are installations used for individual needs. In the Lubusz Voivodship there are thermal installations using RES with a total capacity of about $95 \mathrm{MW}$ [28]. The total demand for thermal energy in the Lubusz Voivodship is $4159 \mathrm{MW}, 42,2 \%$ of which is obtained from coal heating systems, and merely $4,1 \%$ from renewable energy sources [33]. As far as the demand for thermal energy in dwelling houses is concerned, as much as 56,4 \% comes from coal heating systems, and merely $0,1 \%$ from RES.

\section{CHARACTERISTICS OF THE EXISTING CONDITION OF RES IN THE LUBUSZ VOIVODSHIP}

\subsection{Wind energy}

Wind energy is the fastest developing renewable energy source in Poland. The market potential of wind energy is estimated at about $33500 \mathrm{GWh}$ of produced electrical energy [3]. If these resources are to be fully used, it is not enough to build new power plants but network infrastructure will have to be developed as well [23]. Research and the state's policy indicate that there are particularly good conditions for the development of wind energy production in the following regions [19]: 
- the coast of the Baltic Sea, especially in its eastern part,

- the north-east of Poland (near Suwałki and Gołdapia),

- the open and orographically varied area of Warmia, Masuria and Pomerania,

- the sub-mountain regions in southern Poland - mainly in Podkarpacie and Lower-Silesia.

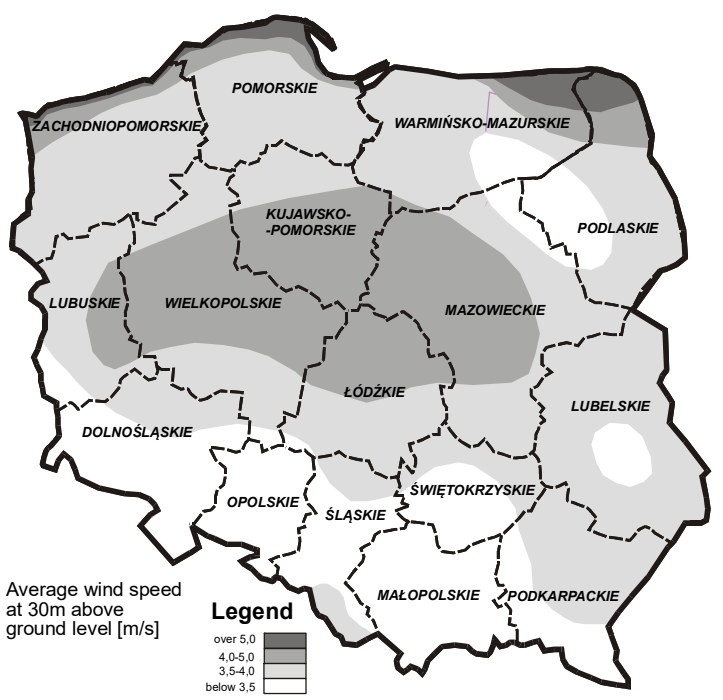

Fig. 6. A map of wind speed zones at $30 \mathrm{~m}$ above ground level. $[\mathrm{m} / \mathrm{s}]$ (Source: prepared by the author, based on [18])

Although the Lubusz Voivodship is not mentioned among the priority areas, it still has good and moderately good conditions for wind energy. Figure 6 presents wind speed zones at $30 \mathrm{~m}$ above ground level and the administrative division of the country. At the moment in the voivodship there are 8 licensed wind energy sources in the counties of: Strzelce-Drezdenko, Słubice, Świebodzin, Krosno, Nowa Sól and Żagań with a total capacity of 63 MW (Table 4).

Table 4. The characteristics of the existing wind farms in the Lubusz Voivodship in 2011. (Source: prepared by the author, based on [28])

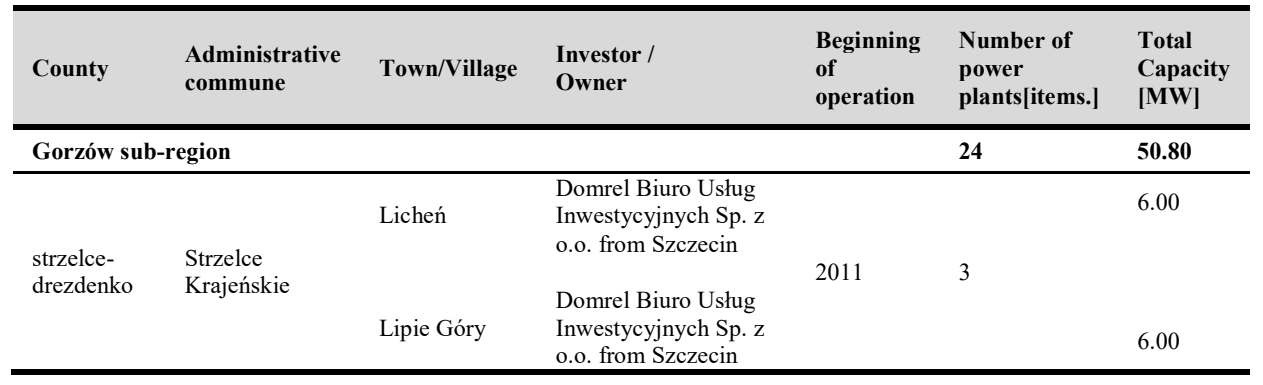


RENEWABLE ENERGY SOURCES IN THE LUBUSZ VOIVODSHIP (POLAND). THE PRESENT CONDITIONS AND PERSPECTIVES FOR DEVELOPMENT

\begin{tabular}{lllllll}
\hline \multirow{2}{*}{ Słubice } & Rzepin & Rzepin & Roman Leszczyński & No data & 2 & 0.80 \\
\cline { 2 - 6 } & Stubice & Golice & $\begin{array}{l}\text { ACCIONA Energy } \\
\text { Poland }\end{array}$ & 2011 & 19 & 38.00 \\
\hline Zielona Góra subregion & & & $\mathbf{8}$ & $\mathbf{1 2 . 3 0}$ \\
\hline Świebodzin & Świebodzin & Glińsk & $\begin{array}{l}\text { Elektrownie Wiatrowe } \\
\text { Karor Sp. z o.o. from } \\
\text { Bydgoszcz }\end{array}$ & 2012 & 3 & 6.00 \\
\hline Krosno & $\begin{array}{l}\text { Krosno } \\
\text { Odrzańskie }\end{array}$ & Osiecznica & Private investor & No data & 1 & 0.30 \\
\hline Nowa Sól & Kożuchów & Stypułów & $\begin{array}{l}\text { ELSETT Elektronis } \\
\text { Sp. j. from Leszno }\end{array}$ & 2011 & 3 & 4.50 \\
\hline Żagań & Szprotawa & Kartowice & $\begin{array}{l}\text { ELSETT Elektronis } \\
\text { Sp. j. from Leszno }\end{array}$ & 2011 & 1 & 1.50 \\
\hline Lubusz Voivodship & & & $\mathbf{3 2}$ & $\mathbf{6 3 . 1 0}$ \\
\hline
\end{tabular}

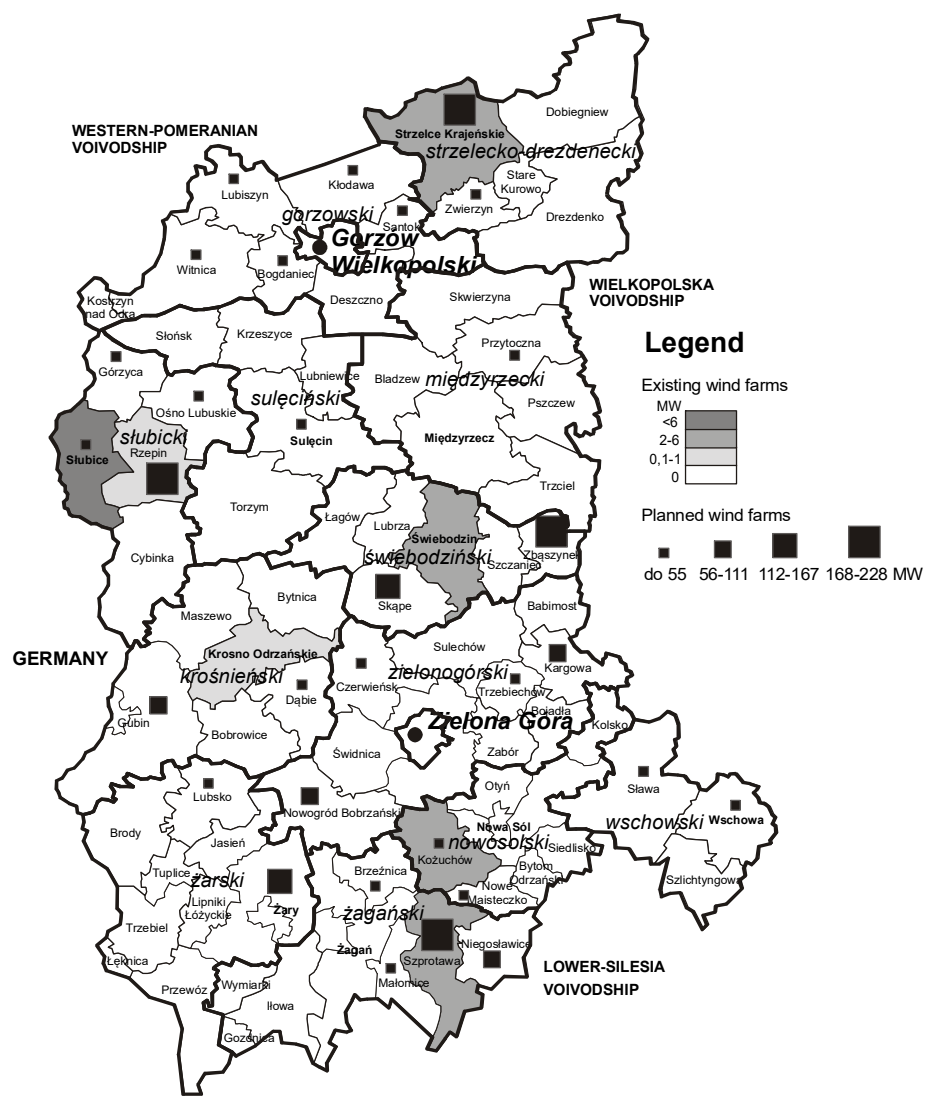

Fig. 7. The existing and planned wind farms (Source: prepared by the author, based on www.lubuskie.pl/news/16806/16/o-nowej-ustwie-OZE, access date: 27 March 2015) 
Perspectives for the development of wind farms in the Lubusz Voivodship in the next few years are optimistic. Preparations are under way to build 66 new wind farms, whose projects are currently being discussed in order to obtain building regulations approval. The total installed capacity of the planned wind farms will be $1834 \mathrm{MW}$ [37]. The wind farms will be located in 31 administrative communes of the Lubusz Voivodship, of which the four largest ones (from 168 to $228 \mathrm{MW}$ ) are planned to be located in the administrative communes of: Strzelce Krajeńskie, Rzepin, Zbąszynek and Szprotawa (Fig. 7).

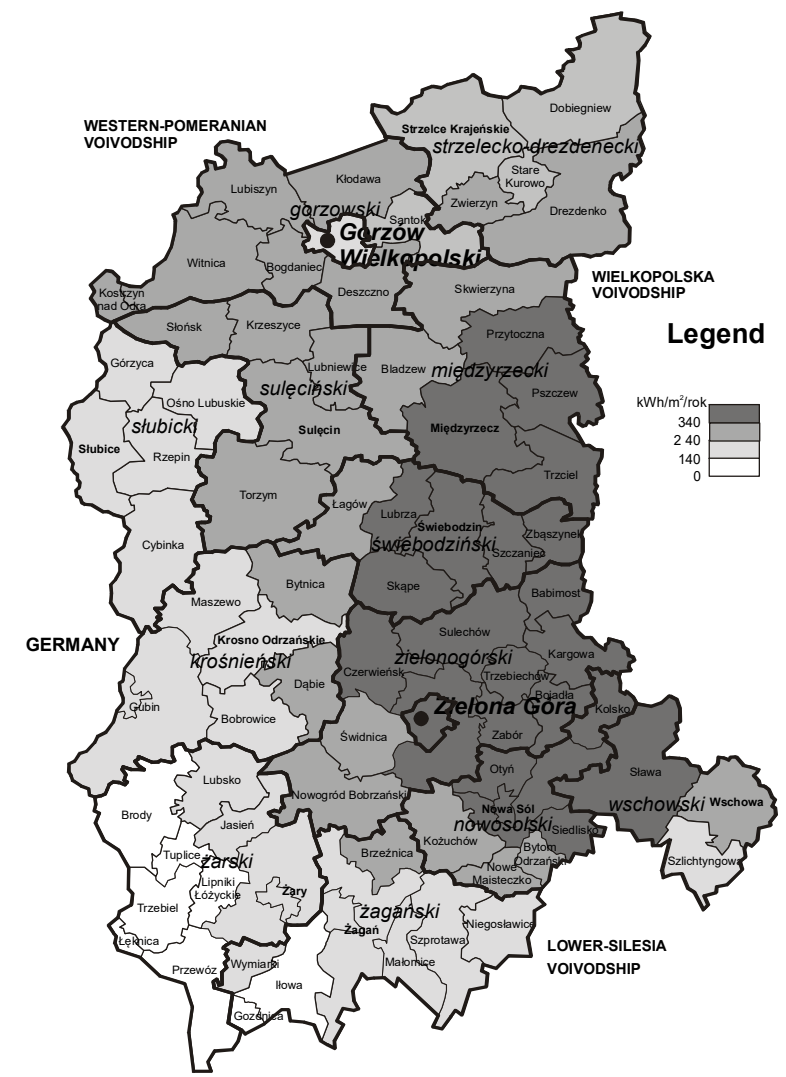

Fig. 8. The wind energy potential $60 \mathrm{~m}$ above ground level in $\left[\mathrm{kWh} / \mathrm{m}^{2} /\right.$ year $]$

(Source: prepared by the author, based on [18])

At the moment in the Lubusz Voivodship instead of building single wind farms there is a tendency to build wind parks with a total capacity of several dozen MW with power generators on masts $100 \mathrm{~m}$ high. In the Lubusz Voivodship at this height the average annual wind speed in open areas reaches 6,6 to $7,8 \mathrm{~m} / \mathrm{s}$ [28]. Assuming that the average wind speed $30 \mathrm{~m}$ above ground level is $3,0-5,0 \mathrm{~m} / \mathrm{s}$ 
(Fig. 6), it is possible to calculate that the wind energy potential possible to achieve with a power generator $60 \mathrm{~m}$ above ground level will be about 180 $\mathrm{kWh} / \mathrm{m}^{2}$ per year [18]. The wind energy potential in particular administrative communes of the Lubusz Voivodship is presented in Figure 8.

The main obstacles to the development of wind energy production are, first of all, a large area of protected land, complicated, time-consuming administrative procedures required when this kind of investment is prepared (lasting about $3 \div 4$ years), lack of detailed local research on wind conditions (taking up to several years), which has to be carried out before an investment is started, and the poorly developed $110 \mathrm{kV}$ network [33]

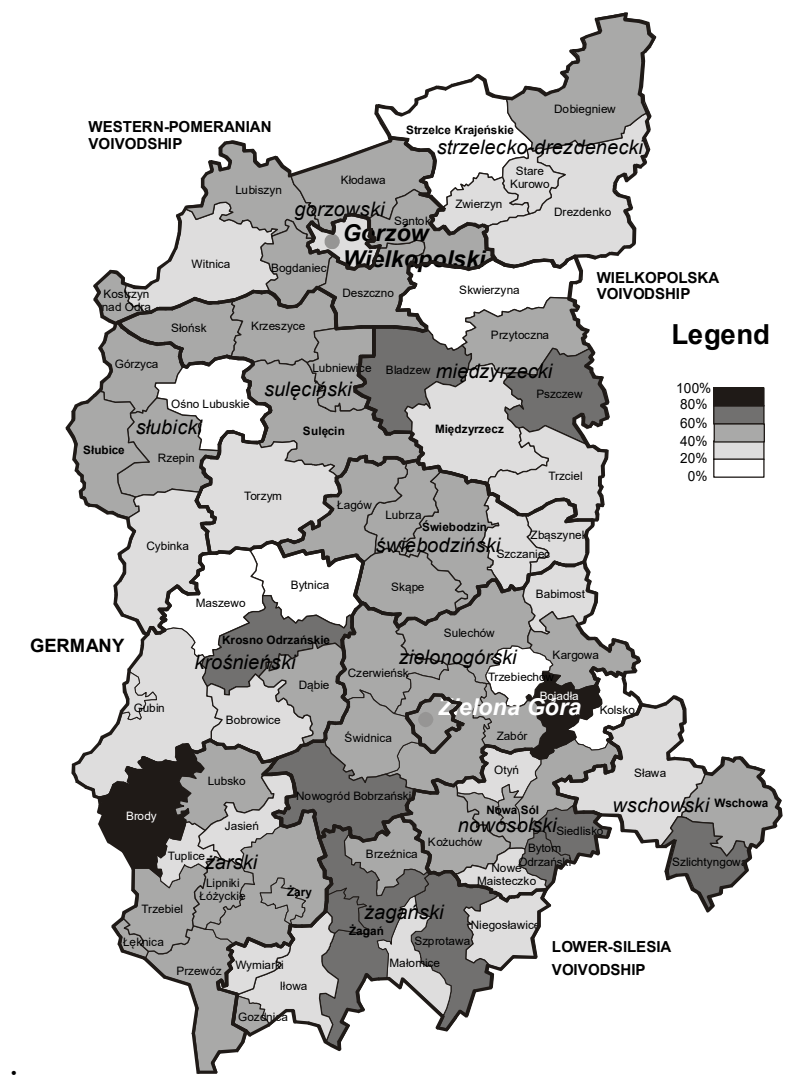

Fig. 9. The social acceptance in [\%] of investments in wind farms in the Lubusz Voivodship (Source: prepared by the author, based on [18])

In the case of wind farms, the social acceptance of new investments is also important. The social acceptance of investments in the construction of wind farms in particular administrative communes of the Lubusz Voivodship is on average 
$45,9 \%$ (Fig. 9). However, it is not the same everywhere in the region. It is much varied in different parts of the voivodship, and social resistance may make new investments much more difficult [18].

\subsection{Solar energy}

Solar energy is systematically gaining in importance in Poland and in the Lubusz Voivodship. There are two important reasons for this. Firstly, the potential of available energy cannot be compared with any other source: the amount of sunlight reaching inhabited areas in Poland is estimated at 28188000 TJ [20]. Secondly, technical conditions make it possible to use small prosumer energy sources providing energy for single households. The average insolation density in Poland is 950 to $1250 \mathrm{kWh} / \mathrm{m}^{2}$ per year (Fig. 10). The highest insolation occurs in the Lublin Voivodship - over $1048 \mathrm{kWh} / \mathrm{m}^{2}$, and the lowest, because of high pollution, in Silesia and near the border between Poland, the Czech Republic and Germany. Solar energy can be transformed into thermal energy (by means of solar collectors) or electrical energy (by means of photovoltaic cells). The climate of our country makes it possible to meet the demand for thermal energy obtained from solar energy in $70 \div 80 \%$ at the most, for this reason an advisable and effective solution is to connect a solar collector through a hot water tank with a gas boiler or a heat pump. Photovoltaic cells are mainly used in detached systems, installed in areas located far from the electrical grid [28].

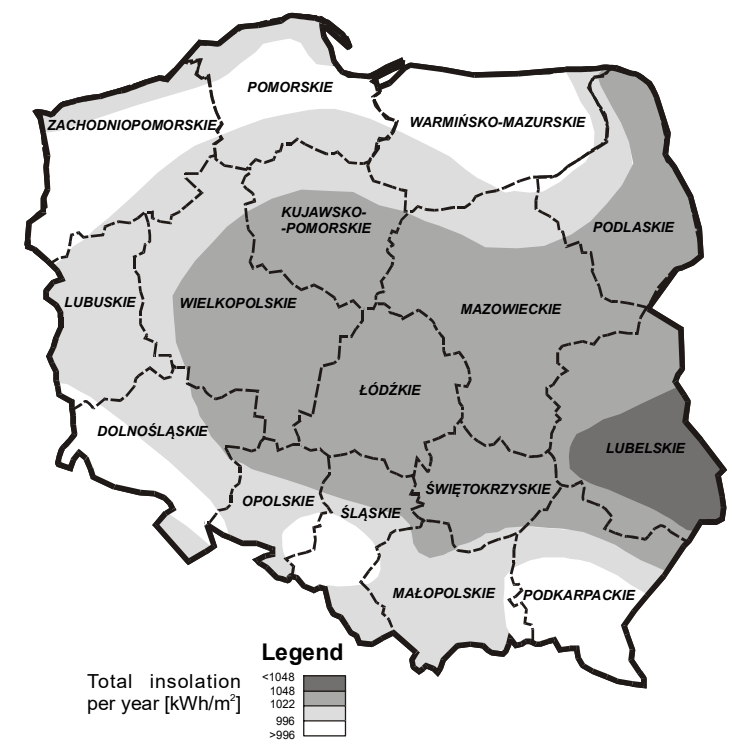

Fig. 10. Total insolation per year $\left[\mathrm{kWh} / \mathrm{m}^{2}\right]$ (Source: prepared by the author, based on www.lubuskie.pl/news/16806/16/o-nowej-ustwie-OZE, access date: 27 March 2015) 
In terms of geographical location the Lubusz Voivodship has sufficient conditions for the development of solar energy production. The average insolation density in the Lubusz Voivodship is up to $1022 \mathrm{kWh} / \mathrm{m}^{2}$ /year (in Poland: $950-1250$ $\mathrm{kWh} / \mathrm{m} 2$ /year), and the average insolation in the voivodship is about 1600 hours per year (Fig. 11), at the same time nearly $80 \%$ of the total sum of annual insolation occurs in the 6 months of spring and summer [28].

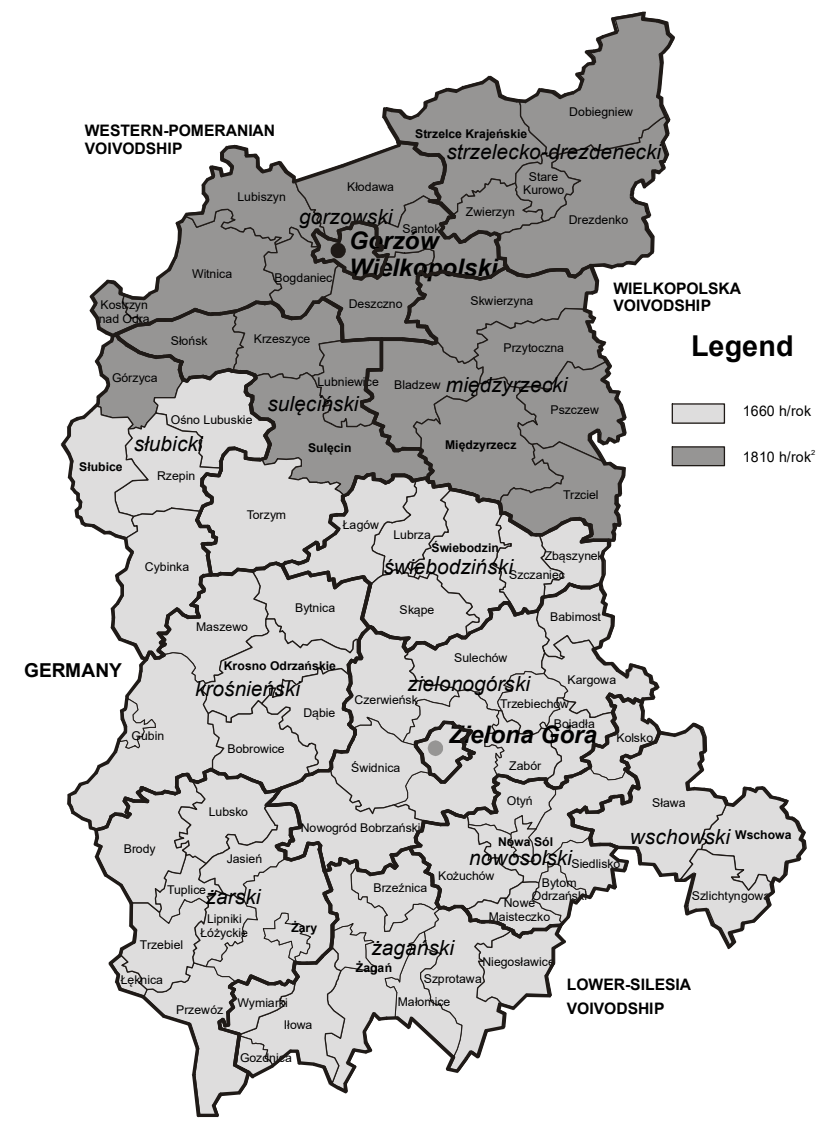

Fig. 11. Insolation in the Lubusz Voivodship [h/year] in the years 1994-2014 (Source: prepared by the author, based on data from the Institute of Meteorology and Water Management)

The average potential of solar energy that can be obtained with a solar collector in the voivodship is $1025,8 \mathrm{MJ} / \mathrm{m}^{2} /$ year. The highest potential occurs in the south and the north east of the voivodship (Fig. 12). 


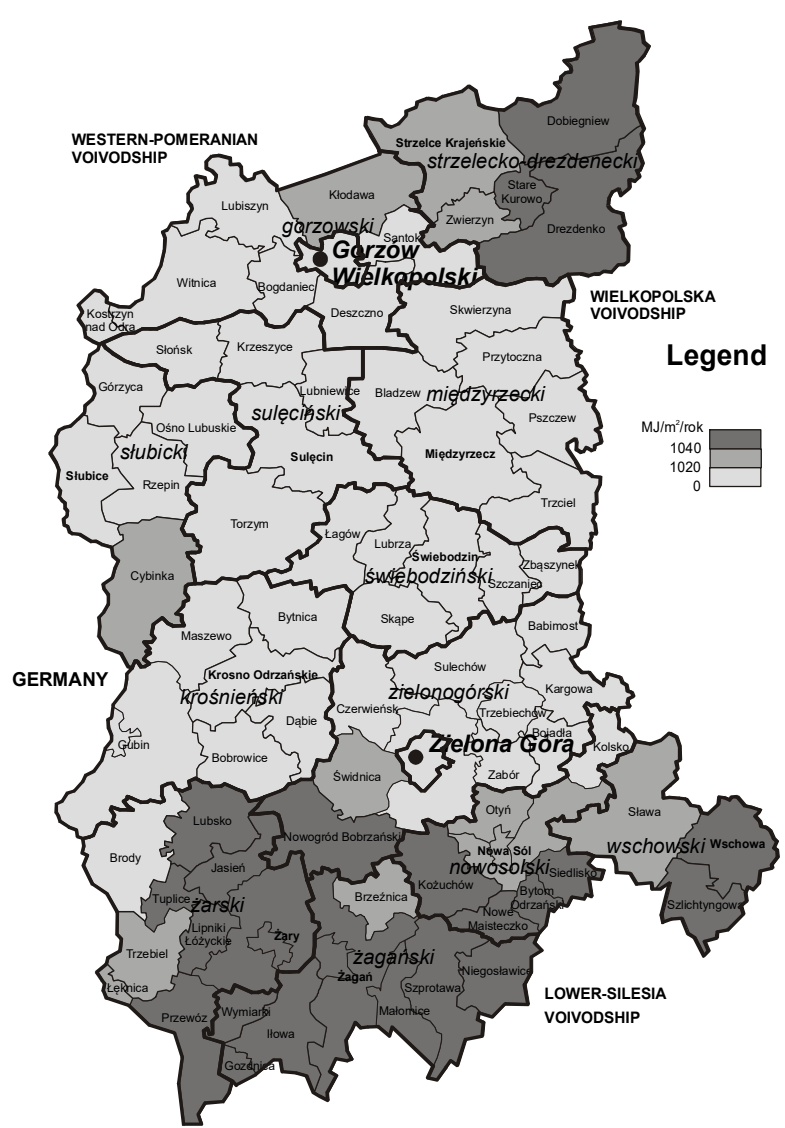

Fig. 12. The potential of solar energy that can be obtained with a solar collector $\left[\mathrm{MJ} / \mathrm{m}^{2} /\right.$ year] (Source: prepared by the author, based on [18])

According to research conditions for the use of solar energy improved at the beginning of the third millennium. For example research on the insolation of Zielona Góra and Gorzów Wlkp., the two largest towns located in the north and south of the Lubusz Voivodship, indicates that there is a considerable regularity of rises and falls in the number of insolation hours. After a year with a rise there comes a year with a fall in the number of insolation hours, and after two years with a fall (2000-2002) two years with a rise (2002-2004). This regularity was slightly broken in the years 2002-2012. In that period there was a rising tendency in the number of sunny hours in both towns (Fig. 13). 


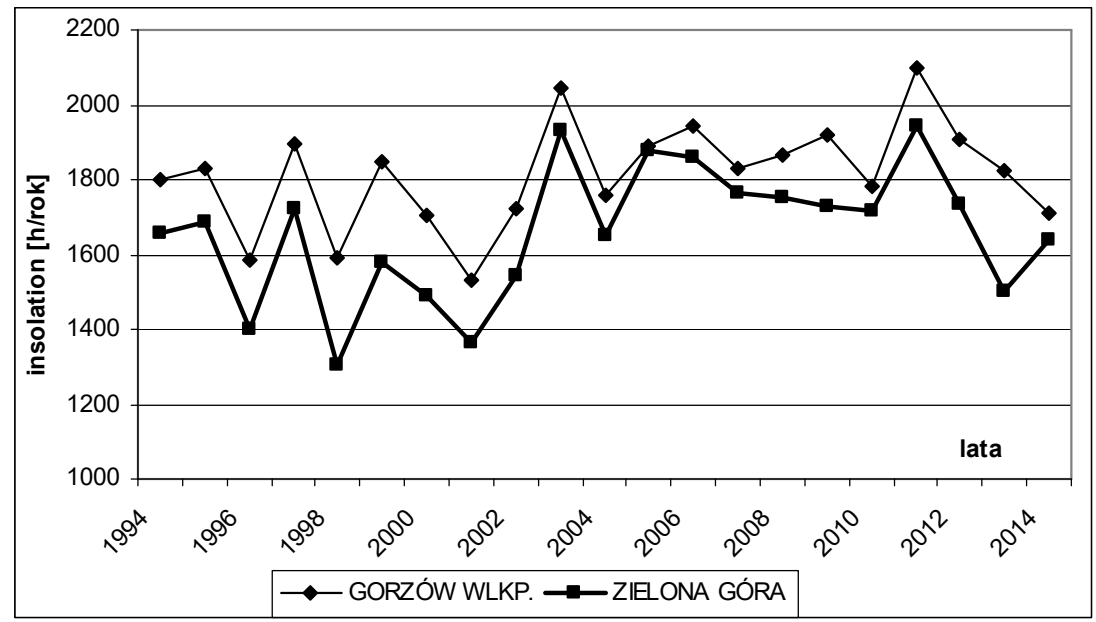

Fig. 13. The insolation of Gorzów Wlkp. and Zielona Góra [h/year] in the years 19942014 (Source: prepared by the author, based on data from the Institute of Meteorology and Water Management)

The research shows that there are more sunny hours per year in the north of the Lubusz Voivodship. Detailed research on insolation in the Lubusz Voivodship shows that it is very stable and predictable. (Fig. 14).

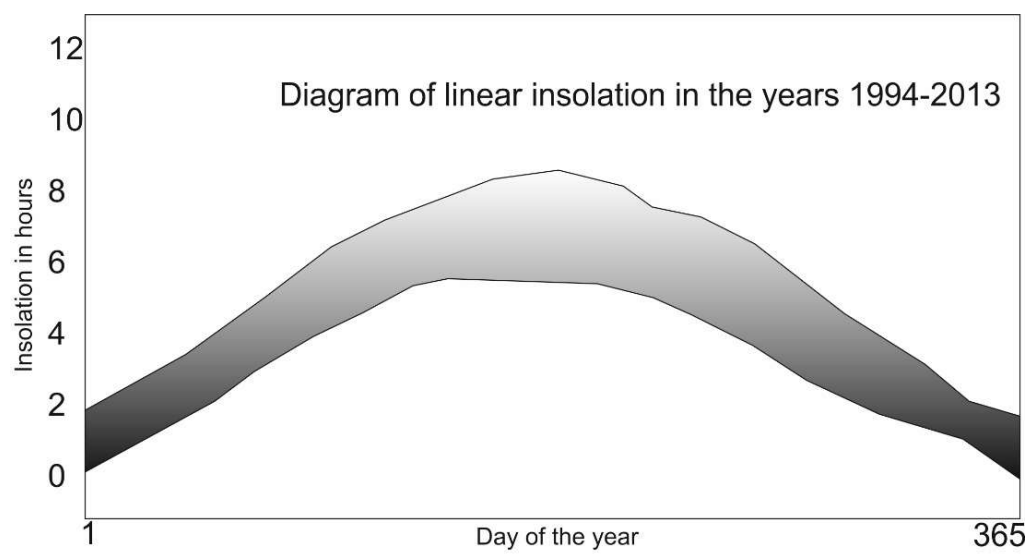

Fig. 14. Insolation in hours on particular days of the year in the town of Zielona Góra in the years 1994-2013 (Source: prepared by the author, based on data from the Institute of Meteorology and Water Management)

According to data from the Energy Regulatory Office [37] there are 119 licensed installations producing electrical in Poland that use solar energy with a total installed capacity of about $21 \mathrm{MW}$. In the Lubusz Voivodship there are 3 licensed 
installations with a total capacity of $1.5 \mathrm{MW}$. In the Lubusz Voivodship actions are being taken to obtained licenses for the construction of 89 photovoltaic power plants (Fig.15). The total installed capacity of these power plants will be $468 \mathrm{MW}$ [37].

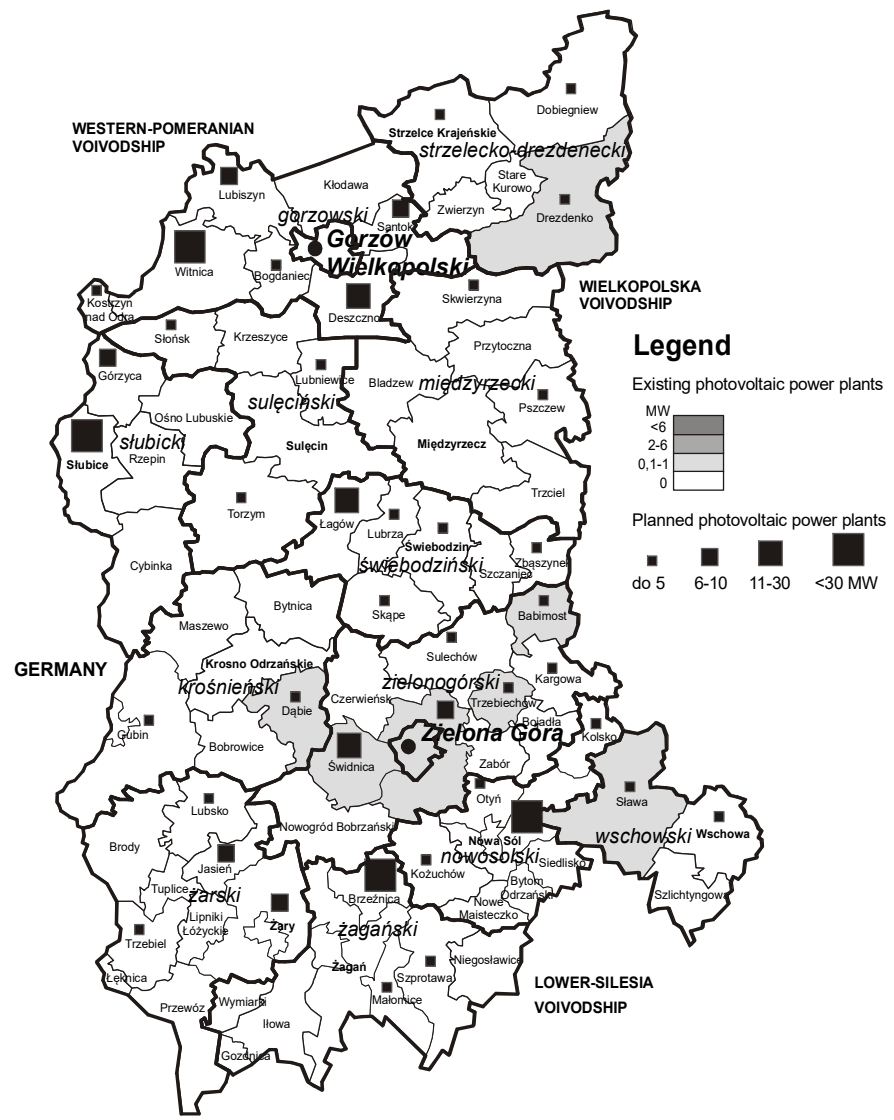

Fig. 15. The existing and planned location of photovoltaic power plants (Source: prepared by the author, based on www.ure.gov.pl, access date: 27 March 2015)

Considerable obstacles to the development of solar energy production are climatic conditions and still high investment costs [33]. A factor favourable to the development of solar energy production is undoubtedly state policy and funds from the European Union for the years 2014-2020. This kind of investment enjoys high social acceptance. The social acceptance of investments in solar energy is very high in the voivodship and it is on average $87,3 \%$ (Fig. 16). 


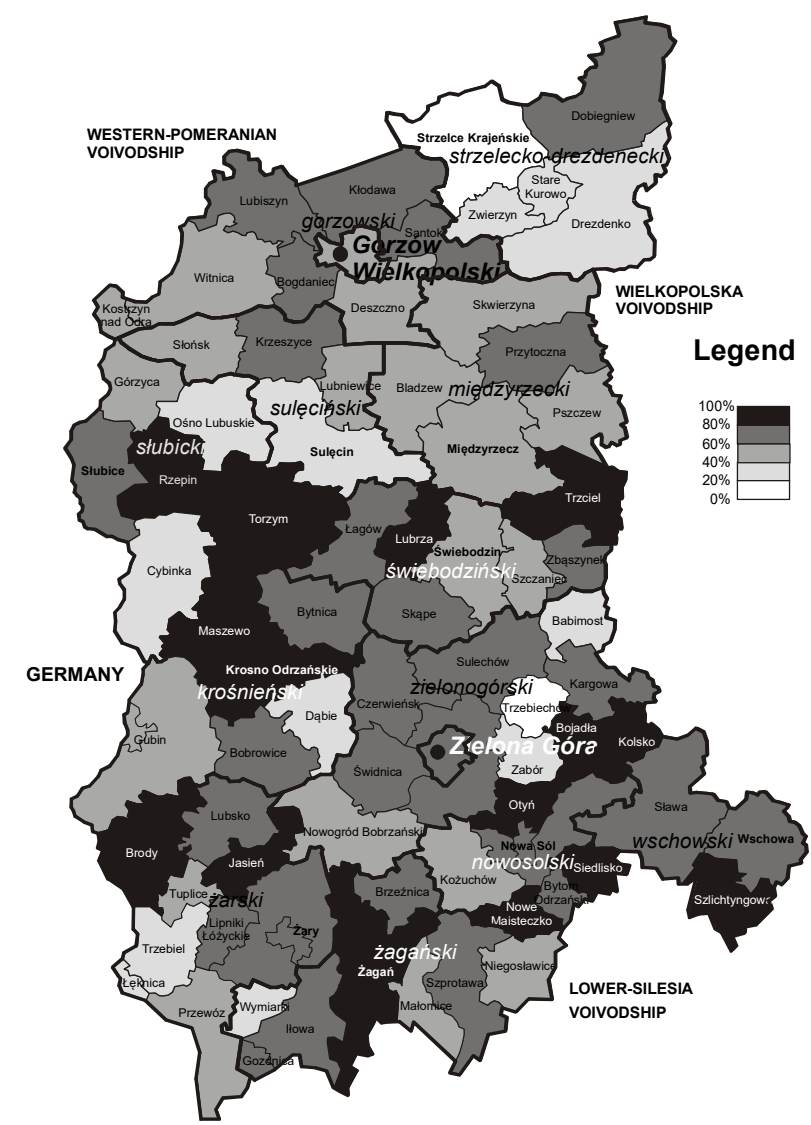

Fig. 16.The social acceptance in [\%] of investments in solar energy in the Lubusz Voivodship (Source: prepared by the author, based on [16])

\subsection{Water energy production}

According to data from the Energy Regulatory Office there are 756 licensed water power plants in Poland with a total installed generation capacity of about $977 \mathrm{MW}$ [37]. The water energy potential of the Lubusz Voivodship (Fig.10) is estimated in terms of technical possibilities at $1544 \mathrm{GWh} /$ year and it is the highest potential on the middle Oder River and the Lusatian Neisse. At present, just a fraction of this potential is used, because the average water energy production is about 270 $\mathrm{GWh} /$ year. 


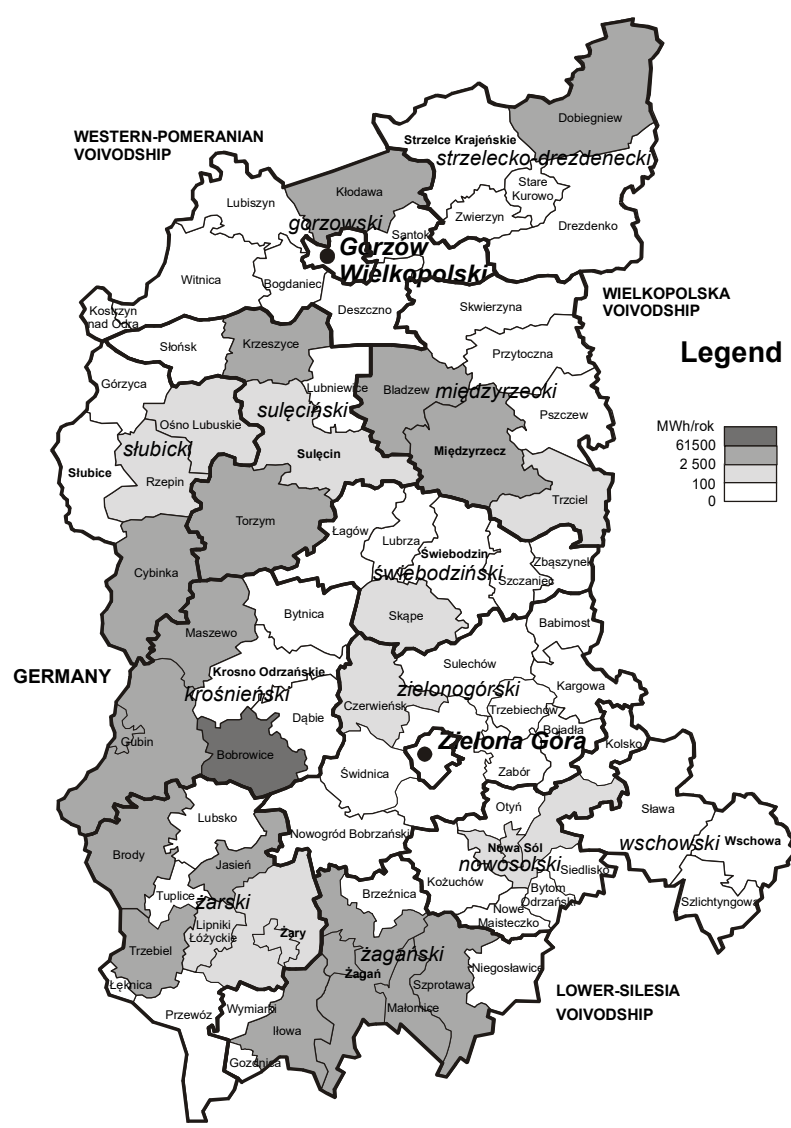

Fig. 17. The water energy potential possible to achieve with the existing dams [MWh/year] (Source: prepared by the author, based on [16])

On 31 December 2014 there were 54 (in 2008 - 50, in 2012 - 56) licensed installations in the area under discussion, with a total installed capacity of about $119 \mathrm{MW}$, which is about $12 \%$ of the installed capacity of the Polish water power plants [28]. The main object in the voivodship is the Dychów Water Power Plant with a generation capacity of about $90 \mathrm{MW}$. There are also 53 other water power plants with a total capacity of about $28 \mathrm{MW}$ [33]. The location of the existing water power plants in the Lubusz Voivodship is presented in Fig.18.

There are plans to build another 21water power plants in the Lubusz Voivodship over the next few years (Fig. 19). Most of them will be small power plants with a capacity of several tens of $\mathrm{kW}$. The only large power plant will be the Zielisko Water Power Plant with a capacity of $58 \mathrm{MW}$, located in the village of Siedlce [37]. 


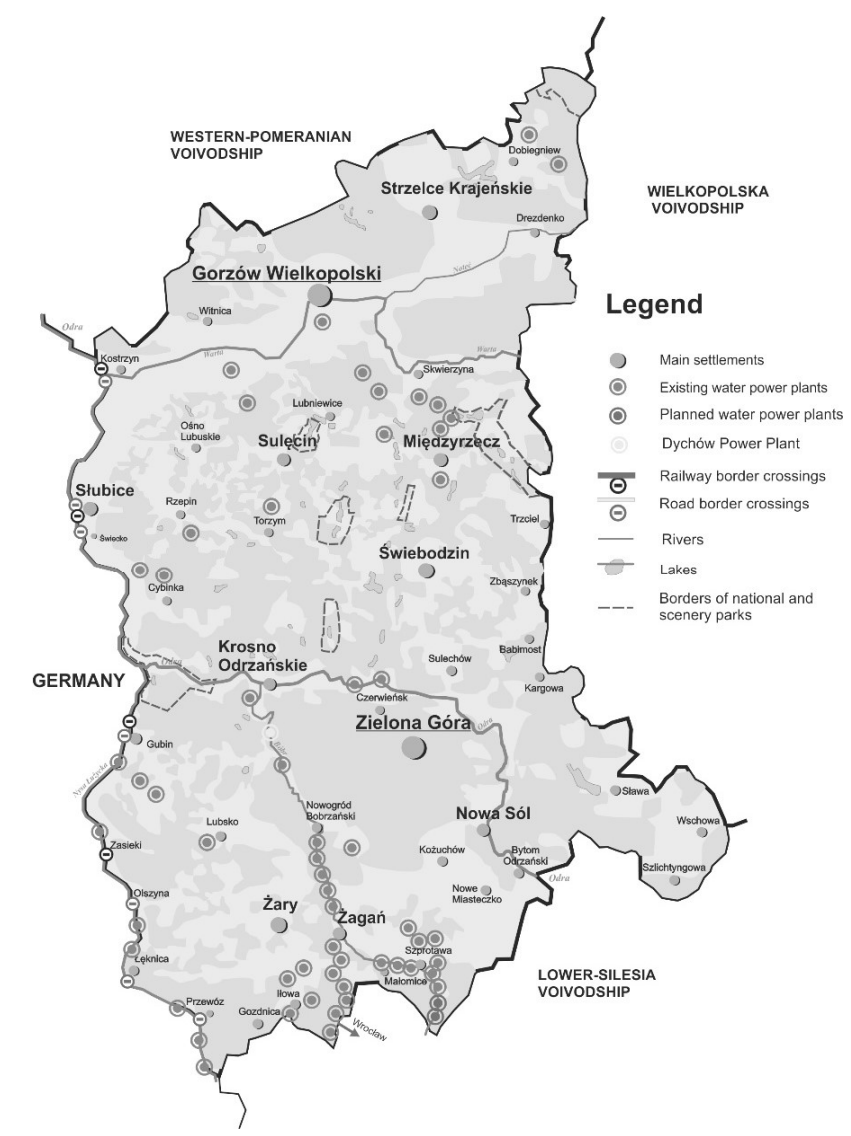

Fig. 18. The existing water power plants in the Lubusz Voivodship (Source: prepared by the author, based on www.lubuskie.pl/news/16806/16/o-nowej-ustwie-OZE, access date: 27 March 2015)

\subsection{Energy from biomass and biogas}

The following forms of biomass are most often used for the production of electrical energy:

- timber wastes from the forest and wood industry,

- energetic plants from dedicated cultivations (e.g. basket willow (Salix viminalis) plantations),

- wastes from municipal green areas,

- cereal straw, straw from oil plants or legumes and hay,

- liquid biofuels (np. plant oils, rape biodiesel, bio-ethane from alcohol factories and agro-refineries), 
- biogas from facilities processing liquid manure, sewage and municipal landfills.

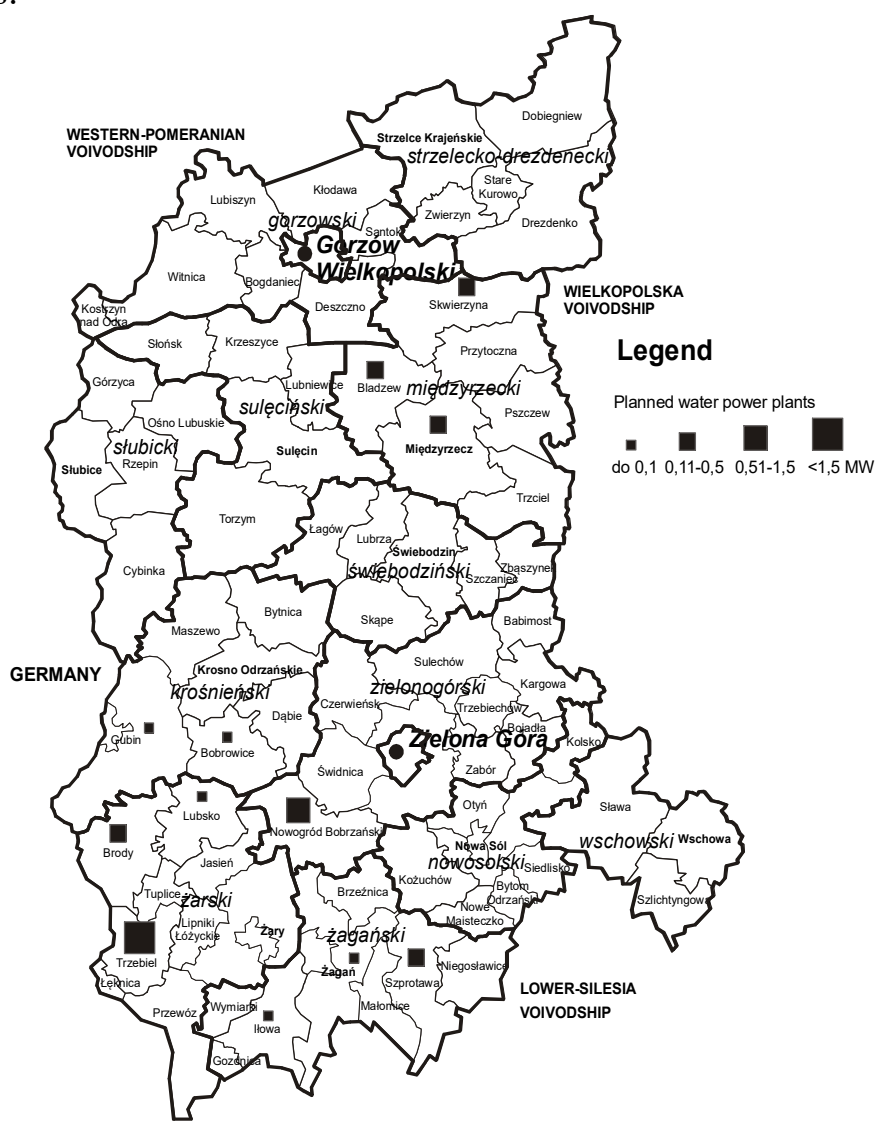

Fig. 19. The installed capacity of the water power plants that are planned to be built in particular administrative communes of the Lubusz Voivodship, (Source: prepared by the author, based on www.ure.gov.pl, access date: 02 November 2015)

The main potential sources of biomass in the voivodship are: straw, plantations of energetic plants and municipal green areas. In 2012 there were 36 operational biomass-fired boiler houses (using wood, timber wastes, straw and pellet fuel) with a total capacity of 87 MW [33]. In the Lubusz Voivodship there are very good conditions for heat production from biomass, especially in the counties of Zielona Góra and Żagań (Fig. 20).

In the Lubusz Voivodship there are good climatic conditions for obtaining biomass. The average annual temperature in the years $1994-2014$ was $9,2^{\circ} \mathrm{C}$, and the precipitation was $9,61 / \mathrm{m}^{2} /$ year [13] (Fig. 21). 


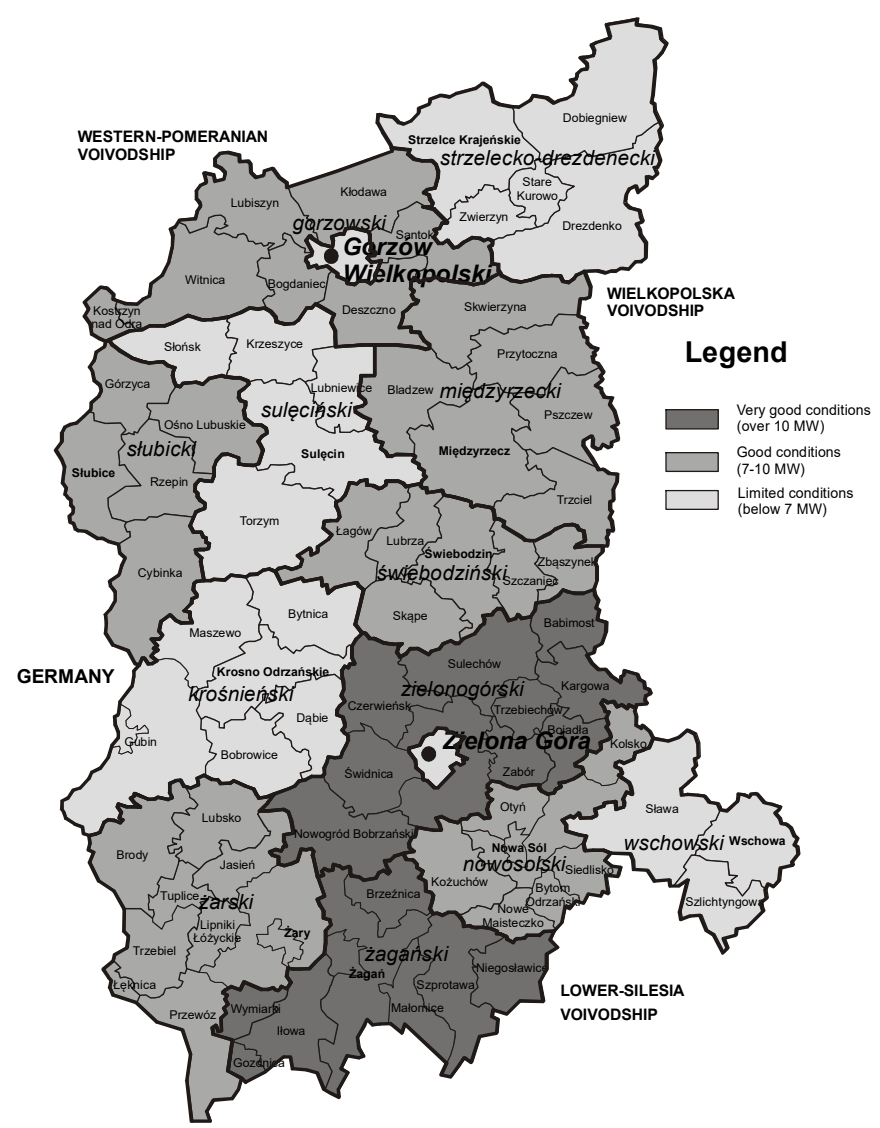

Fig. 20. The conditions for obtaining biomass in the Lubusz Voivodship (Source: prepared by the author, based on www.lubuskie.pl/news/16806/16/o-nowej-ustwie-OZE, access date: 27 March 2015)

The afforestation rate in the Lubusz Voivodship is about $50 \%$ of the whole area of the voivodship. This situation leads to the dynamic development of the wood industry (e.g. Kronopol Sp. z o.o. located in Żary, Homanit Krosno Odrzańskie Sp. z o.o.), which means that wood industry companies need to be provided with resources by the forest inspectorates of the Regional Management of State Forests in Zielona Góra and Szczecin. Moreover, the forest inspectorates allow local people in rural areas to collect small branches to be used as fuel for heating in households. In such a situation in the Lubusz Voivodship there is no wood available as biomass for thermal or electrical energy production. However, wastes from the abovementioned wood industry plants are used for energy production [28]. 


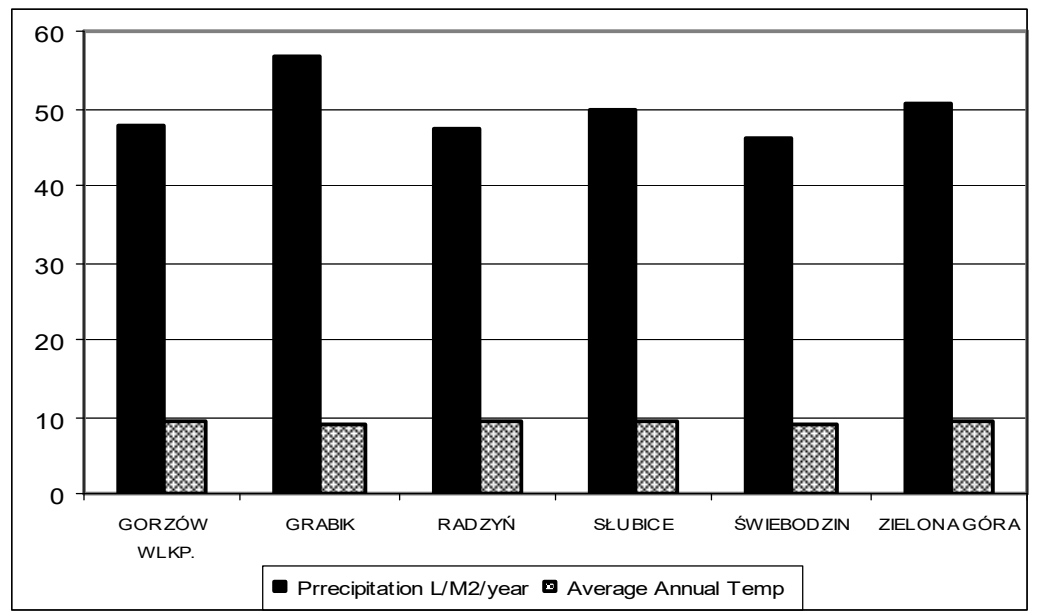

Fig 21. The average annual temperature and precipitation in the Lubusz Voivodship (Source: prepared by the author, based on data from the Institute of Meteorology and Water Management)

In the Lubusz Voivodship there are mostly sandy soils (of little agricultural use), podzolic and pseudo podzolic soils, which belong to soil quality class $\mathrm{V}$ and class VI. In general in the Lubusz Voivodship the poorest and poor soils amount to $44,1 \%$ of the total arable land, medium-quality soils and medium poor soils (classes IVa and IVb) $36.0 \%$, very good and medium good soils (classes II, IIIa, IIIb) $18,3 \%$. There are not any soils belonging to the best class - class I in the Lubusz voivodship [22]. Since there are mostly low productivity soils in the Lubusz Voivodship, it has good conditions for cultivating energetic plants, which have good annual growth, a good calorific value, considerable immunity to illnesses and pests and relatively low requirements in terms of soil. In the Lubusz Voivodship the area of arable land potentially useful for the cultivation of energetic plants is about 24 thousand ha [16]. The basket (energetic) willow (Salix viminalis) is most often grown in the Lubusz Voivodship. Its dry-wood biomass has a calorific value of about. $16 \mathrm{MJ} / \mathrm{kg}$ and it is used in the form of wood particles for direct combustion or in the form of briquettes or pellets. A large amount of energetic material is exported to Germany [28].

The area used for the cultivation of the basket willow (Salix viminalis) has increased considerably in the Lubusz Voivodship over the past few years [21]. The research and reviews carried out in 2012 to prepare a strategy for the energy industry in the Lubusz Voivodship showed that plantations of the energetic willow comprised an area of about 1140 ha and that was more by $45 \%$ than in 2008. The energy potential of this type of plantation in the voivodship is as follows: total resources $-3800 \mathrm{Mg} / \mathrm{year}$, a potential value of annual thermal 
energy production $-50 \mathrm{TJ} / \mathrm{year}$ and a potential value of thermal power $-9 \mathrm{MW}$ [15].

During routine work on the maintenance of parks, green squares, lawns, alleys and plants growing on street sides, it is possible to obtain biomass (wastes) from municipal green areas. Municipal green areas comprise about 1300 ha, assuming that $2 \mathrm{Mg}$ of green mass are collected from a hectare with a calorific value of $14 \mathrm{MJ} / \mathrm{kg}$, it is possible to obtain a potential of thermal power of $5 \mathrm{MW}$ and thermal energy production of about $30 \mathrm{TJ} /$ year [33].

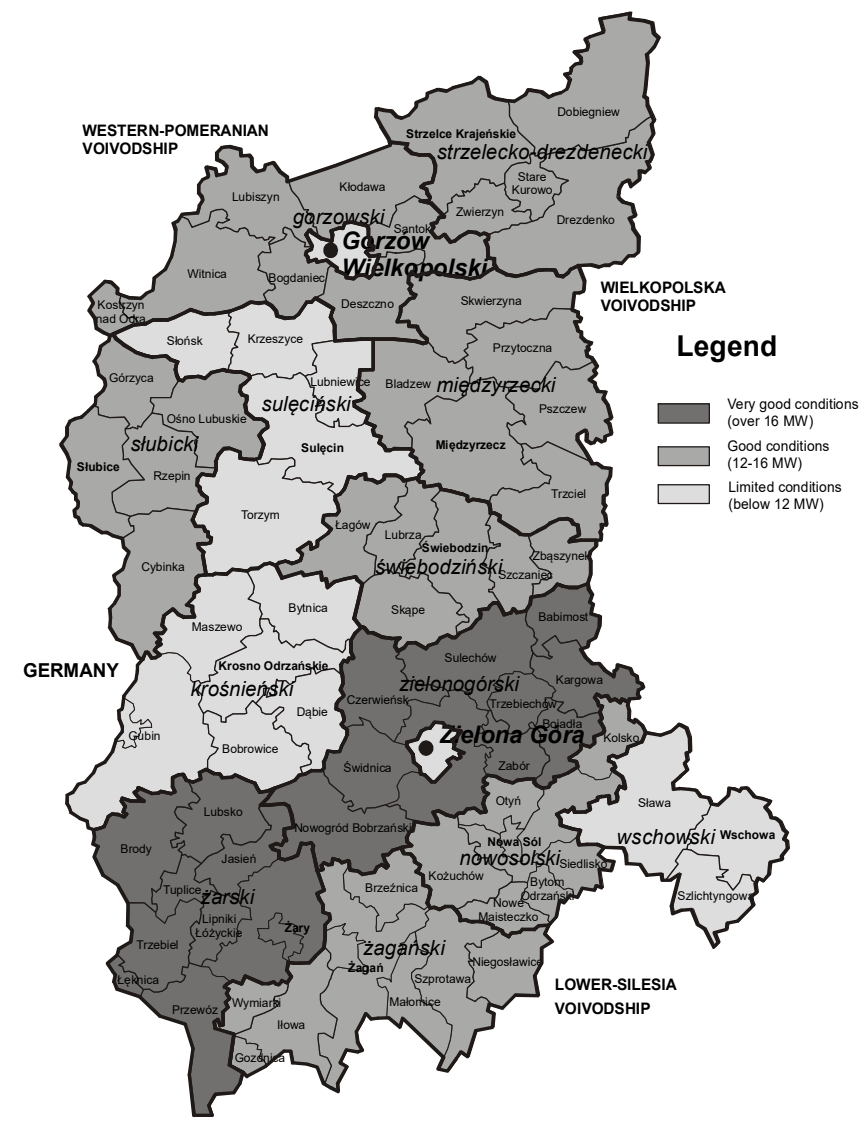

Fig. 22. The conditions for the production of biogas in the Lubusz Voivodship (Source: prepared by the author, based on www.lubuskie.pl/news/16806/16/o-nowej-ustwie-OZE, access date: 27 March 2015)

At present, the area of arable land in the Lubusz Voivodship is 402 thousand ha [36]. Assuming that $50 \%$ of this area is used for cereals, on average it is possible to obtain $1.5 \mathrm{Mg} / \mathrm{ha}$ of straw, and the calorific value of straw is $14 \mathrm{MJ} / \mathrm{kg}$, then 
the total amount of straw will be $301500 \mathrm{Mg} /$ year. If we also assume that the participation of straw as fuel for energy production is $10 \%$, then a possible amount of straw for thermal energy production is $30150 \mathrm{Mg} / \mathrm{year}$, which provides about $338 \mathrm{TJ} /$ year of potential annual thermal energy production and about $60 \mathrm{MW}$ of potential thermal power.

These approximate calculations indicate that the total energy generation potential of the Lubusz Voivodship in terms of the use of biomass is $418 \mathrm{TJ} /$ year out of the potential annual amount of thermal energy production, and the potential amount of thermal power is about $74 \mathrm{MW}$.

In the Lubusz Voivodship there are good conditions for the production of biogas (Fig. 22), and there are plans to build 26 objects with an estimated total capacity of about $32 \mathrm{MW}$ [37]. Moreover, there are 22 large farms and/or processing plants with a potential for using biogas for effective energy production [28]. An analysis of landfills carried out by the Research and Development Centre of Municipal Ecology shows that 1 tonne of wet wastes from households and businesses gives $80-160 \mathrm{~m}^{3}$ of landfill gas. The use of landfill gas for energy production is profitable in the case of landfills with a total area of over 3 ha, a depth of at least $5 \mathrm{~m}$ and where the total mass of wastes is at least $0,5^{*} 10^{6} \mathrm{t}$. It is noteworthy that landfill gas is intensively produced for 10-15 years after the exploitation of the biogas deposit is finished [28]. In the future less landfill gas will be produced because the form and structure of wastes change as a result of waste segregation and restrictions on the amount of wastes in landfills, including biodegradable ones.

According to data from the Energy Regulatory Office there are 254 licensed installations using biogas in Poland [3]. The total capacity of biogas installations is about 188,5 MW [10]. In the Lubusz Voivodship there are 7 licensed biogas installations with a total capacity of about $3,9 \mathrm{MW}$, which is about $2.7 \%$ of the power produced by biogas power plants in Poland. The biogas plants are located in Gorzów Wielkopolski (1) and in the counties of Krosno (1), Zielona Góra (4) and Nowa Sól (1). The biogas plants in the Lubusz Voivodship produce biogas:

- from sewage treatment plants -2 power plants with a total installed capacity of $0,6 \mathrm{MW}$;

- from a landfill - 2 power plants with a total installed capacity of 0,5 MW,

- agricultural biogas in 3 biogas plants with a total installed capacity of 2,4 MW.

Breeding farms and sewage treatment plants produce large amounts of highly polluted wastes. The only ecologically acceptable method for utilizing these wastes is anaerobic fermentation. In the Lubusz Voivodship biogas is mainly produced through anaerobic fermentation from [28]:

- animal faeces, i.e. animal manure, 
- sediments from sewage treatment plants,

- organic wastes.

In the Lubusz Voivodship there are 3 registered existing objects producing agricultural biogas with a total electric power generation capacity of about 2.4 MW and a thermal capacity of 2,7 MW [28], located in: Kalsk (the administrative commune of Sulechów), Klępsk (the administrative commune of Sulechów) and Niedoradz (the administrative commune of Otyń). Moreover, in the Lubusz Voivodship there are 87 municipal sewage treatment plants. At present, there are 2 registered sewage treatment plants with a capacity of $0,8 \mathrm{MW}$, and in the case of 24 objects there is a potential possibility of using biogas for energy production [33].

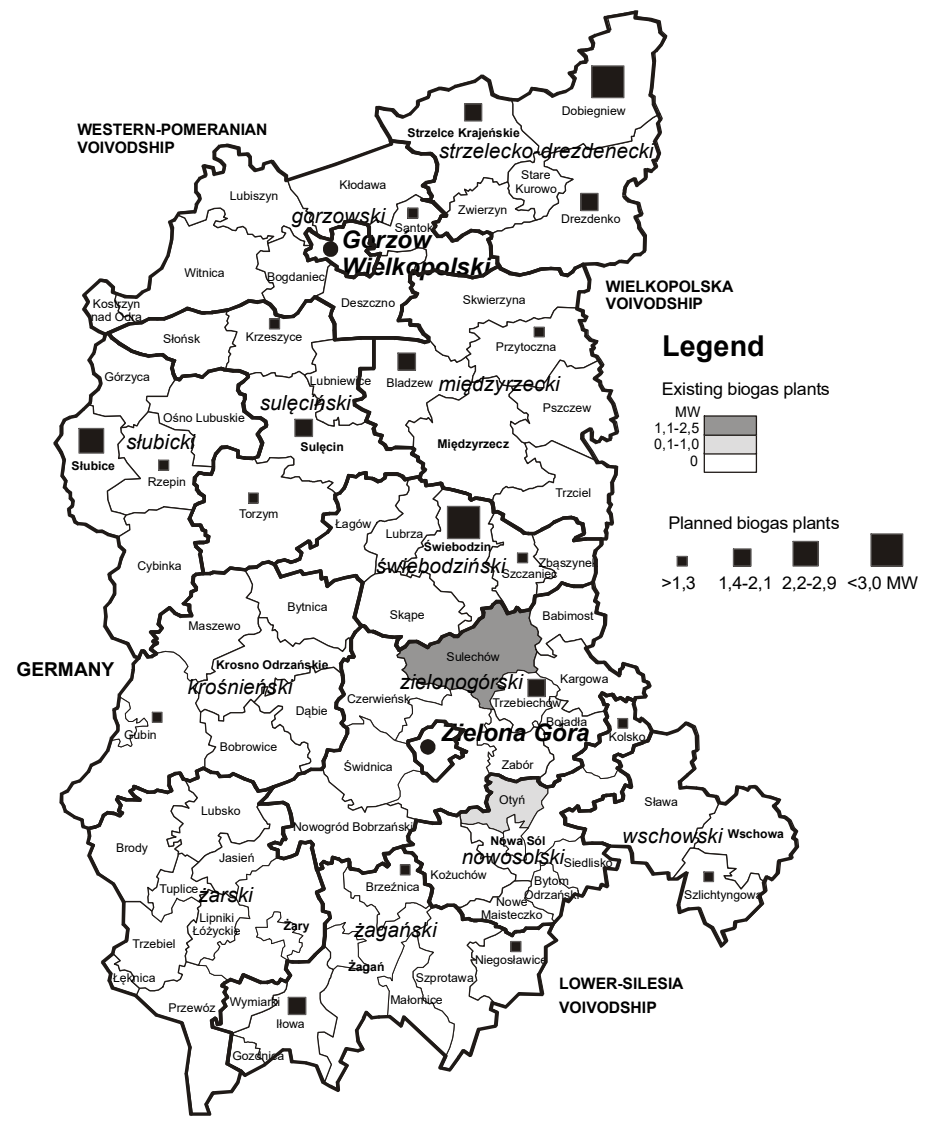

Fig. 23. The existing and planned biogas plants (Source: prepared by the author, based on www.ure.gov.pl, access date: 02 November 2015) 
In the Lubusz Voivodship biogas is also obtained from municipal landfills. In 2010 there were 21 landfills with wastes other than dangerous or neutral, where municipal wastes were deposited. Biogas is only obtained from two landfills with a total capacity of $0.7 \mathrm{MW}$ [33]. One of the municipal landfills where landfill biogas is used for energy production is the landfill in Racula (in the administrative commune of Zielona Góra) [28]. There are plans to build another 28 biogas plants with a total installed capacity of 0.6 to $2.1 \mathrm{MW}$ (Fig. 23).

The social acceptance of biogas plants is low in the Lubusz Voivodship, on average $35,2 \%$ (Fig. 24) [18].

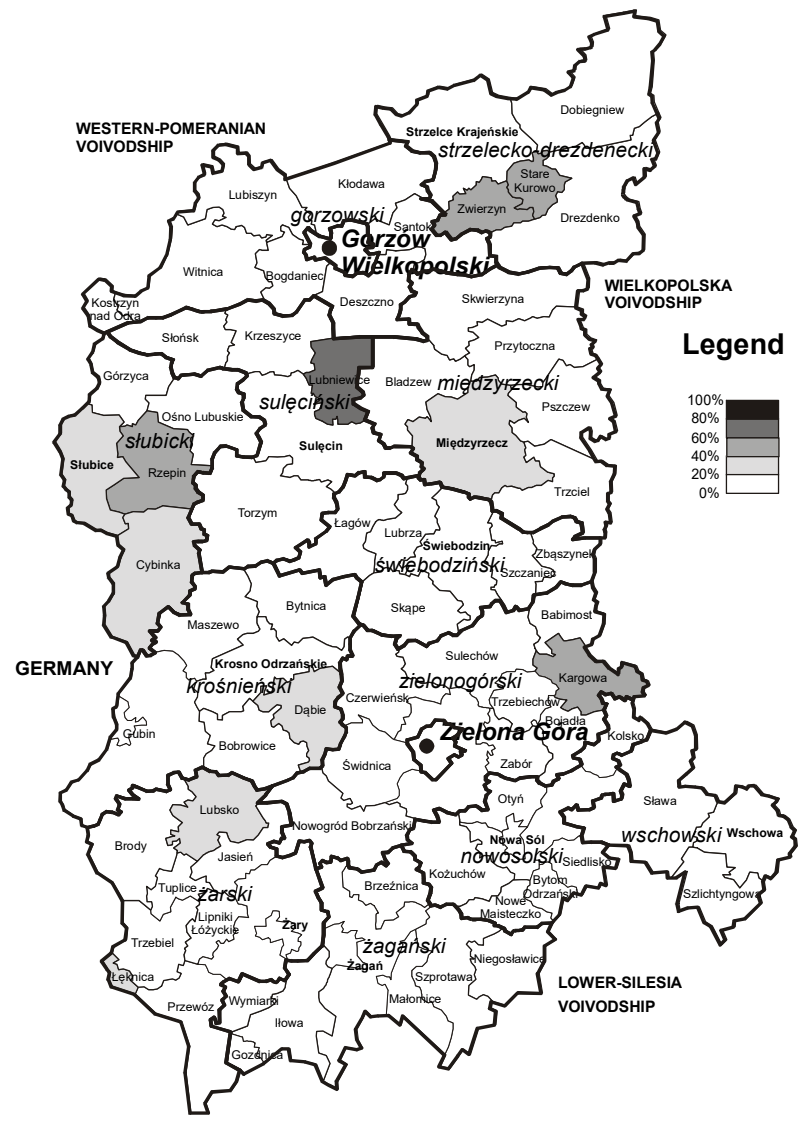

Fig. 24. The social acceptance in [\%] of investments in biogas in the Lubusz Voivodship (Source: prepared by the author, based on [16]) 


\subsection{Geothermal energy}

In the geological structure of Poland there are geothermal water reservoirs with temperatures from 20 to over $100^{\circ} \mathrm{C}$ at the depth of 1500 to $3500 \mathrm{~m}$ [20]. In nearly $2 / 3$ of the area of Poland there are good conditions for the development of geothermal energy production [13]. In Poland the greatest heat flux density occurs in the Lubusz Voivodship [32,34] (Fig. 25).

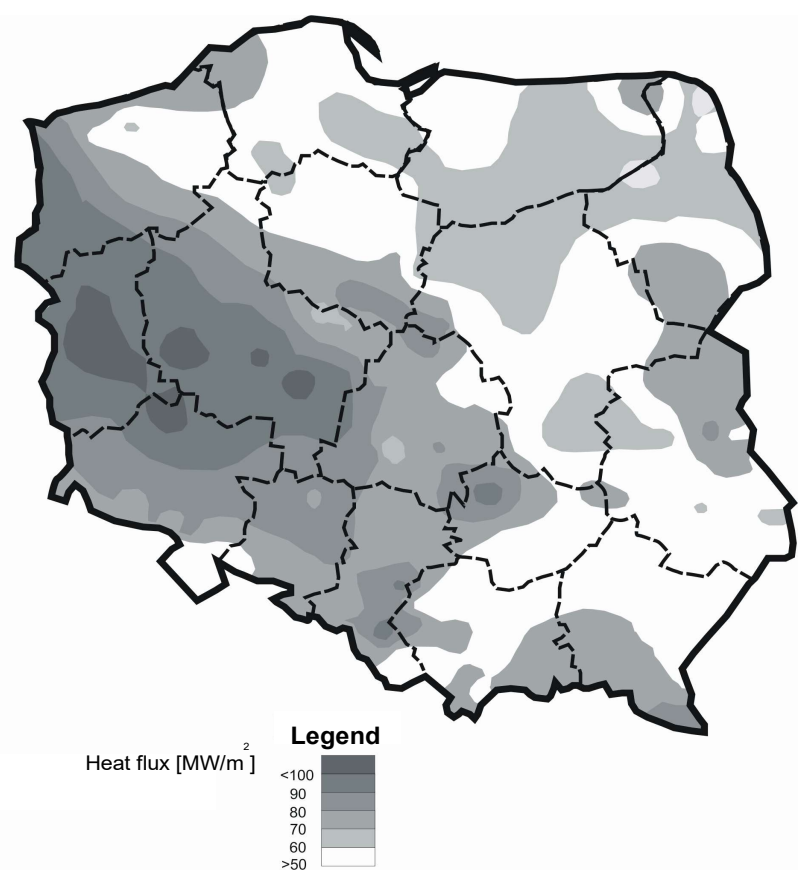

Fig. 25. A map of the heat flux density in Poland

All administrative communes of the Lubusz Voivodship have conditions and resources which make it possible to use geothermal water energy [26]. The temperature of water at the depth of about $2000 \mathrm{~m}$ sometimes reaches over $100^{\circ} \mathrm{C}$ (e.g. Pszczew, Trzciel $110^{\circ} \mathrm{C}$ ), but in most cases it does not exceed $80^{\circ} \mathrm{C}$ (e.g. Szprotawa, Żagań - about $80^{\circ} \mathrm{C}$, Świebodzin, Bledzew - about $50^{\circ} \mathrm{C}$ ) [1]. The main areas with geothermal waters are located in the north west of the voivodship, near the border with the Western-Pomeranian Voivodship [28]. 


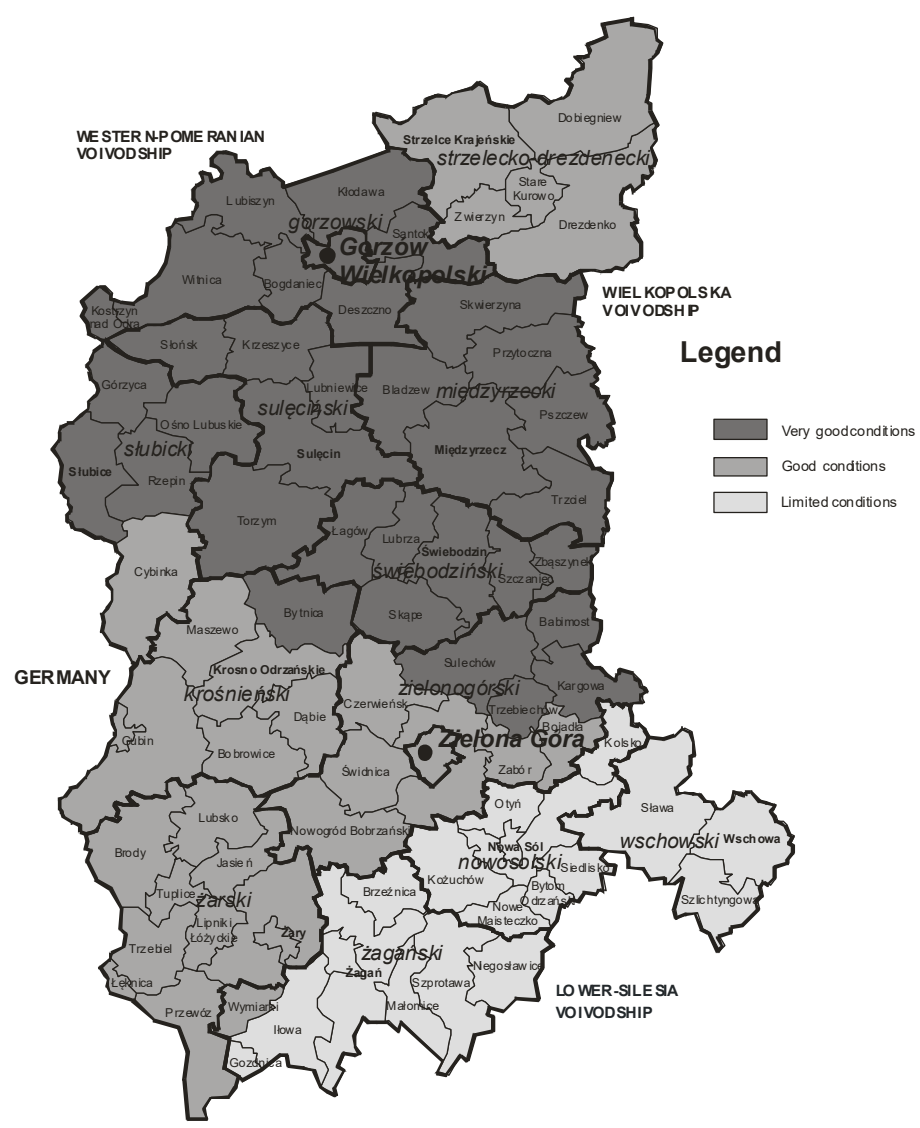

Fig. 26. The conditions for using geothermal energy in the Lubusz Voivodship (Source: prepared by the author, based on www.lubuskie.pl/news/16806/16/o-nowej-ustwie-OZE, access date: 27 March 2015)

Although there are mostly very good and good conditions for using geothermal energy in the Lubusz Voivodship (Fig. 26), at present there are no deep drilling installations (able to drill boreholes deeper than 1000m) in our region. At the same time there are a number of individual installations using heat pumps for heating buildings and for obtaining hot water for everyday use (for example educational institutions, resorts, swimming pools and private houses). The main obstacle to the development of geothermal energy use are high operating costs $[8,9]$ and the necessity to carry out detailed geological research as early as the planning stage [33]. 


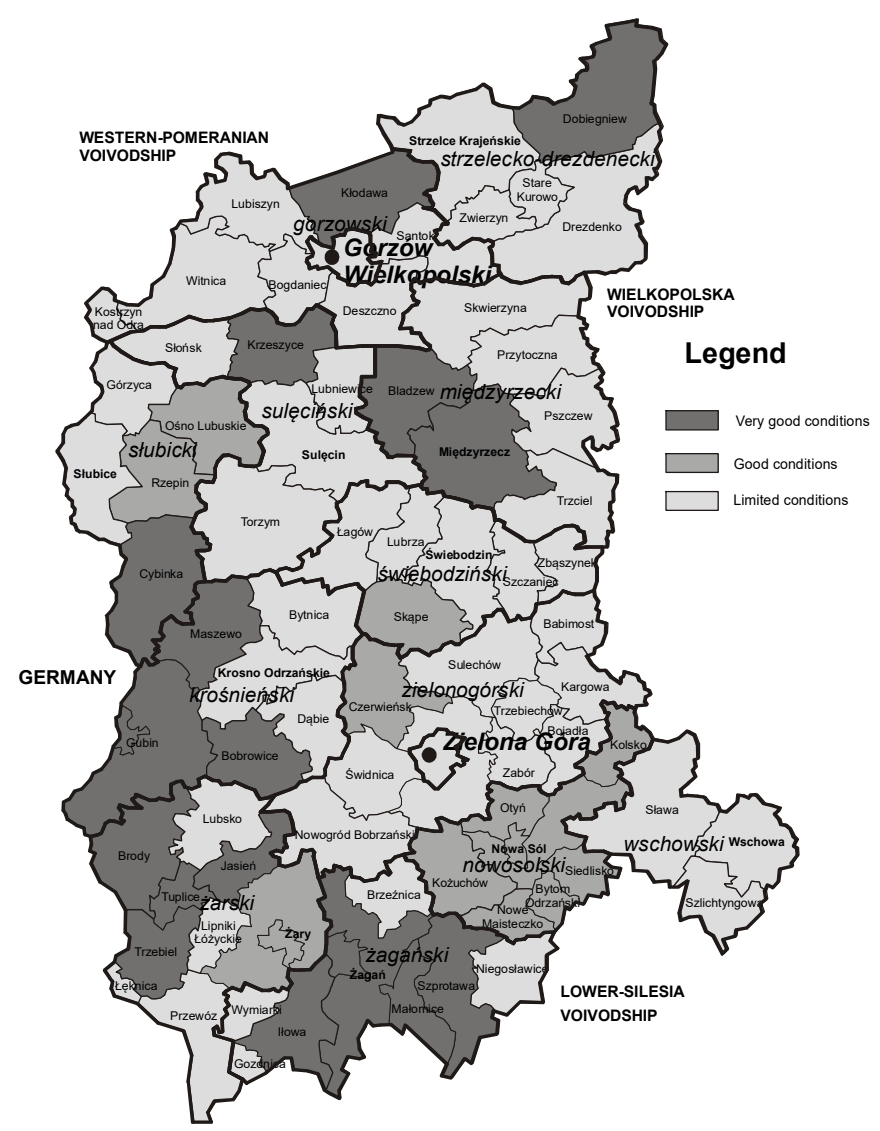

Fig. 27. The total thermal and electrical energy potential estimated in particular administrative communes of the Lubusz Voivodship.

\section{CONCLUSIONS}

The Institute for Renewable Energy predicts that in Poland in the years 2015 2020 the participation of RES in the planned increment of energy production and the use of its potential will be $28 \%$ at the most in the case of the use of biomass as an energy source, $19 \%$ in the case of wind energy, and in the case of photovoltaic energy it will be the lowest [33]. In comparison with the other voivodships, the Lubusz Voivodship has relatively small renewable energy resources (Table 5). However, a large number of investments are planned, which will provide many more possibilities of using renewable energy sources. Current research proves that it is possible to increase the potential of RES in the Lubusz Voivodship in the case of: 
- wind energy because of the location of a large part of the voivodship in a favourable wind speed zone and because the accessibility and density of power lines (Fig. 8.),

- water energy because of the possibility of building new water power plants on favourably located but unused segments of the rivers (Fig. 18),

- solar energy because of the technological possibilities and efficiency of solar collector systems, easy accessibility and the possibility of obtaining preferential loans and financial aid from the budget (Fig. 12),

- geothermal energy, in particular from shallow geothermal waters because of the geological conditions and lower installation and operational costs of heat pumps in comparison with installations necessary to obtain energy from deep geothermal waters,

- energy from biomass and biogas because of the widespread occurrence, different origin and versatility (Fig. 22).

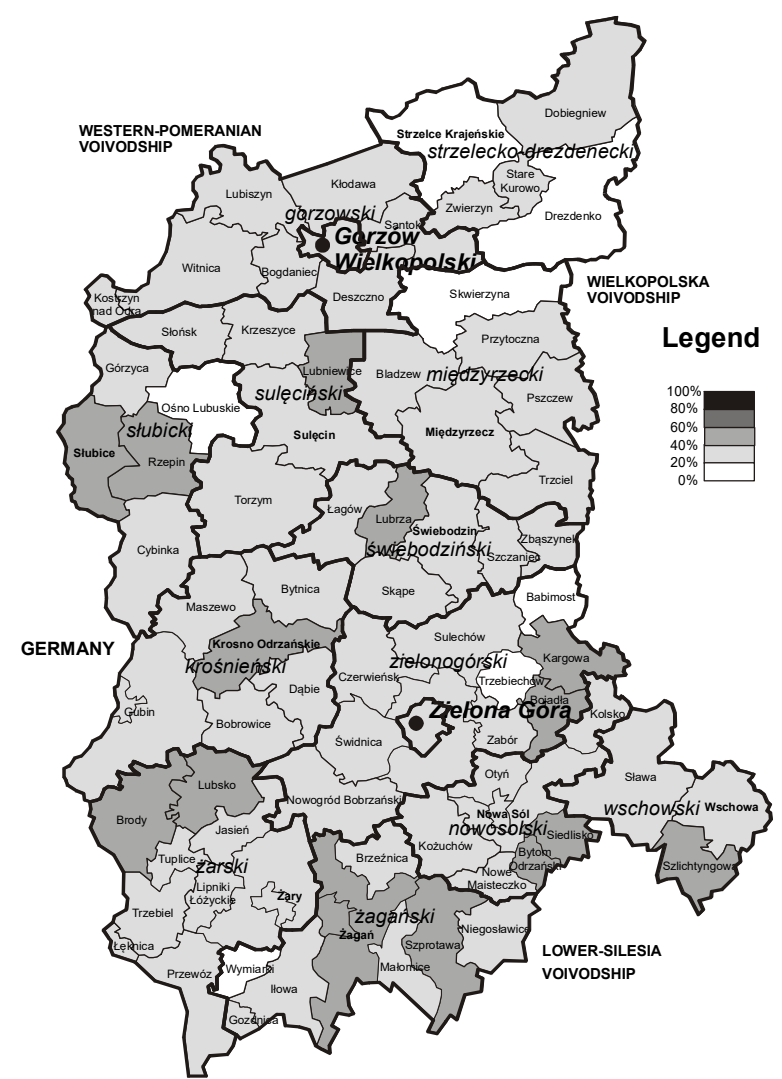

Fig. 28. The social acceptance in [\%] of investments in RES in particular administrative communes of the Lubusz Voivodship (Source: prepared by the author, based on [18]) 
In comparison with the other regions of Poland the Lubusz Voivodship has a moderate potential for the development of renewable energy sources. The voivodship has a relatively high potential for developing the use of energy obtained from the sun, wind and shallow geothermal waters [30,31].

The best conditions for the development of renewable energy occur in the Lubusz Voivodship near the border with the Lower-Silesia Voivodship, on the PolishGerman border and in the administrative communes of Kłodawa and Dobiegniew. The relatively low social acceptance of investments in RES could be a problem. In most administrative communes of the Lubusz Voivodship it is $20-40 \%$. Only in nine administrative communes it exceeds $40 \%$.

Table 5. The assessment of RES potentials in particular voivodships in Poland in the years 2015 - 2020, (Source: based on: www.lubuskie.pl/news/16806/16/o-nowejustwie-OZE, access date: 27 March 2015)

\begin{tabular}{|c|c|c|c|c|c|c|c|c|c|c|c|c|c|c|c|c|c|c|}
\hline & 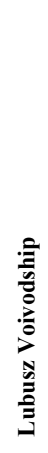 & 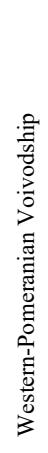 & 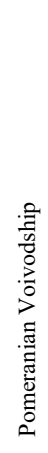 & 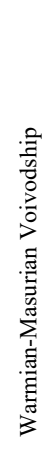 & 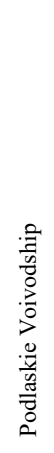 & 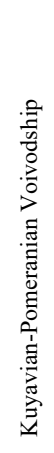 & 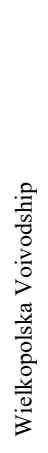 & 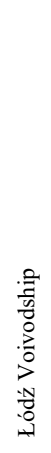 & 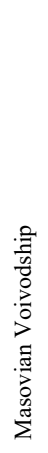 & 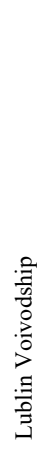 & 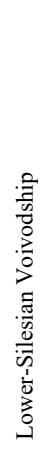 & $\begin{array}{l}\text { 离 } \\
\text { v } \\
0 \\
: 0 \\
0 \\
0 \\
0 \\
0 \\
0 \\
0\end{array}$ & 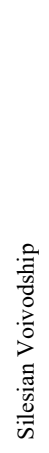 & 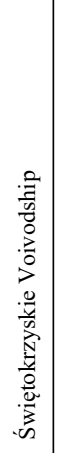 & 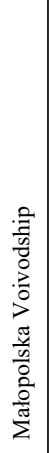 & 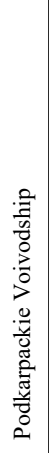 & 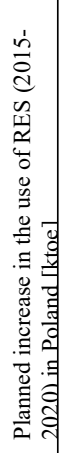 & 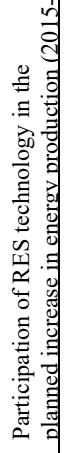 \\
\hline $\begin{array}{l}\text { Wind } \\
\text { energy }\end{array}$ & & & & & & & & & & & & & & & & & $\begin{array}{r}75 \\
0 \\
\end{array}$ & $\begin{array}{l}19 \\
\% \\
\end{array}$ \\
\hline $\begin{array}{l}\text { Small } \\
\text { wind } \\
\text { energy } \\
\text { producti } \\
\text { on }\end{array}$ & & & & & & & & & & & & & & & & & 37 & $1 \%$ \\
\hline $\begin{array}{l}\text { Solar } \\
\text { thermal } \\
\text { energy }\end{array}$ & & & & & & & & & & & & & & & & & $\begin{array}{r}39 \\
2\end{array}$ & $\begin{array}{l}13 \\
\%\end{array}$ \\
\hline $\begin{array}{l}\text { Photovol } \\
\text { taic } \\
\text { energy }\end{array}$ & & & & & & & & & & & & & & & & & $\begin{array}{r}0.0 \\
9\end{array}$ & $0 \%$ \\
\hline $\begin{array}{l}\text { Agricult } \\
\text { ural } \\
\text { biogas }\end{array}$ & & & & & & & & & & & & & & & & & $\begin{array}{r}38 \\
4\end{array}$ & $\begin{array}{l}12 \\
\%\end{array}$ \\
\hline $\begin{array}{l}\text { Biomass } \\
\text { from } \\
\text { crops }\end{array}$ & & & & & & & & & & & & & & & & & $\begin{array}{r}81 \\
2\end{array}$ & $\begin{array}{l}28 \\
\%\end{array}$ \\
\hline $\begin{array}{l}\text { Straw } \\
\text { biomass }\end{array}$ & & & & & & & & & & & & & & & & & & \\
\hline $\begin{array}{l}\text { Forrest } \\
\text { biomass }\end{array}$ & & & & & & & & & & & & & & & & & 0 & $0 \%$ \\
\hline
\end{tabular}




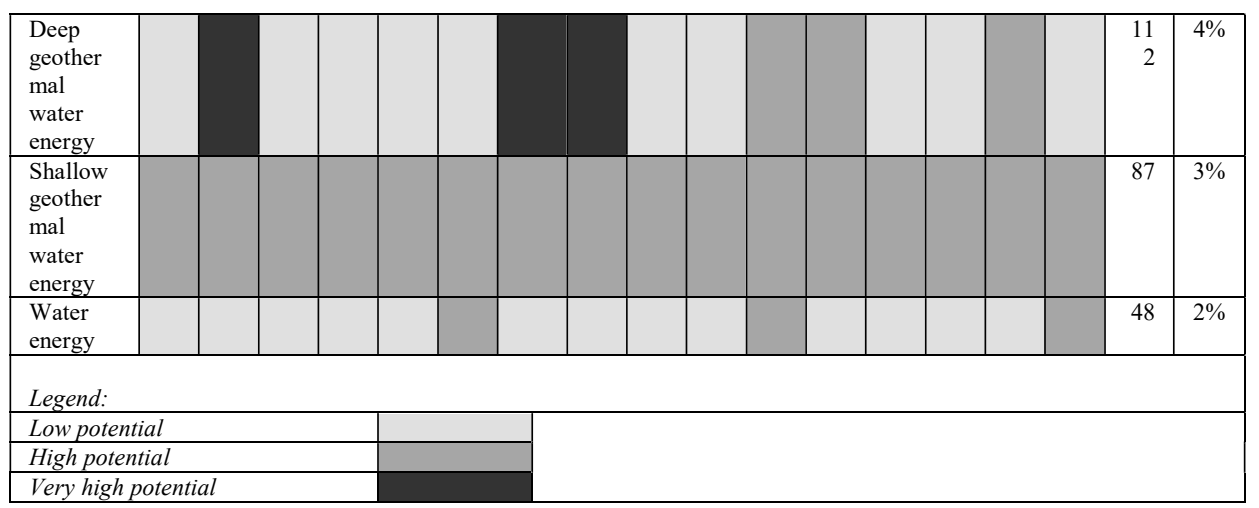

\section{REFERENCES}

1. Barbacki A.: Classification of geothermal resources in Poland by exergy analysis Comparative study, Renewable and Sustainable Energy Reviews 16, (2012) 123-128.

2. Bazan-Krzywoszańska A., Mrówczyńska M., Skiba M., Łączak A.: Economic conditions for the development of energy efficient civil engineering using RES in the policy of cohesion of the European Union (2014-2020). Case study: the town of Zielona Góra, Energy and Buildings 118 (2016) 170-180.

3. Brzeźińska-Rawa A., Goździewska-Biechońska J.: Recent development in the wind Energy sector in Poland, Renewable and Sustainable Energy Reviews 38 (2014) 79-87.

4. Dyrektywa Parlamentu Europejskiego i Rady 2009/28/WE z dnia 23 kwietnia 2009 r. w sprawie promowania stosowania energii ze źródeł odnawialnych zmieniająca i w następstwie uchylająca dyrektywy 2001/77/WE oraz 2003/30/WE (Tekst mający znaczenie dla EOG) (Dz.U.UE L z dnia 5 czerwca 2009 r.).

5. Dzikuć M.: Bezpieczeństwo energetyczne miast $i$ wsi województwa lubuskiego. Rynek Energii 104, 1 (2013) 56-61.

6. Energia ze źródeł odnawialnych w 2013 roku, Główny Urząd Statystyczny, Warszawa 2014 (In Polish).

7. Farat R., Mager P. Kasprowicz T.: Warunki klimatyczne województwa lubuskiego, Zielona Góra 2014.

8. Hofmeister M, Baastrup A.: Business models on geothermal DH systems. Holm Green Energy Association 2014.

9. Huculak M., Jaraczewski W., Dej M.: Economic aspects of the use deep geothermal heat in district heating in Poland, Renewable and Sustainable Energy Reviews 49 (2015) 29-40. 
10. Igliński B., Buczkowski R., Cichosz M.: Biogas in Poland - Current state, potential and perspectives, Renewable and Sustainable Energy Reviews 50 (2015) 685-695.

11. Igliński B., Buczkowski R., Cichosz M., Kujawski W.: Renewable energy in the Kujawsko-Pomorskie Voivodship (Poland), Renewable and Sustainable Energy Reviews 14 (2010) 1336-1341.

12. Igliński B., Buczkowski R., Cichosz M., Piechota G., Kujawski W., Płaskacz M.: Renewable energy production in the Zachodniopomorskie Voivodship (Poland), Renewable and Sustainable Energy Reviews 27 (2013) 768-777.

13. Igliński B., Buczkowski R., Kujawski W., Cichosz M., Piechota G.: Geoenergy in Poland, Renewable and Sustainable Energy Reviews 16 (2012) 2545-2557.

14. Igliński B, Iglińska A, Kujawski W, Buczkowski R, Cichosz M.: Bioenergy in Poland. Renewable and Sustainable Energy Reviews 15 (2011) 2999 3007.

15. Igliński B., Piechota G., Buczkowski R.: Development of biomass in Polish energy sector: an overview. Clean Technol Environ Policy 17 (2015) 317-29.

16. Janiszewska D.A.: Potencjat energetyczny upraw wierzby na gruntach marginalnych $w$ Polsce, Zeszyty Naukowe Politechniki Koszalińskiej, Koszalin 2012.

17. KazakJ., van Hoof J., Szewranski S.: Challenges in the wind turbines location process in Central Europe - The use of spatial decision support systems. Renewable and Sustainable Energy Reviews 76 (2017) 425-433.

18. Kuczyński T. i inni: Innowacyjność podejmowanych działań $w$ obszarze odnawialnych źródet energii, Zielona Góra 2008.

19. Krajowy Plan Działań $w$ zakresie energii ze źródel odnawialnych, Ministerstwo Środowiska, 2010.

20. Określenie potencjatu energetycznego regionów Polski $w$ zakresie odnawialnych źródel energii, pod red. G. Wiśniewskiego, Instytut Energetyki Odnawialnej, Warszawa 2011.

21. Oniszak-Popławska A., Zowsik M., Wiśniewski G.: Produkcja $i$ wykorzystanie biogazu rolniczego. Instytut Energii Odnawialnej, Warszawa 2003 (in Polish).

22. Plan gospodarki odpadami dla województwa lubuskiego na lata 2012-2017 z perspektywa do 2020 roku, www.lubuskie.pl.

23. Polityka Energetyczna Polski do 2030, www.bip.msp.gov.pl, przyjęta przez Radę Ministrów 10 listopada 2009. 
24. Skrzypczak I., Kokoszka W., Zientek D., Kogut J.: Monitoring of landslide areas with the use of contemporary methods of measuring and mapping. Civil and Environmental Engineering Reports 241 (2017) 69-82.

25. Sliz-Szkliniarz B.: Assessment of the renewable Energy-mix and land use trade-off at a regional level: A case stady for the Kujawsko-Pomorskie Voivodship, Renewable and Sustainable Energy Reviews 35 (2013) 257-270.

26. Sokołowski J.: The geothermal resources of Poland and their potential use in environmental protection. Technology of Geological Exploration Geosynoptics and Geothermics 5-6 (1993) 67-80 (in Polish).

27. Statistical Yearbook Lubuskie Voivodship, Statistical Office in Zielona Góra 3 (2014).

28. Strategia Energetyki Województwa Lubuskiego, Załącznik nr 1: Analiza stanu istniejącego systemów energetycznych, www.lubuskie.pl.

29. Strategia energetyki województwa lubuskiego, Załącznik nr 2: Założenia do strategii i potencjalne możliwości rozwoju w perspektywie do roku 2030, www.lubuskie.pl.

30. Staszczuk A., Kuczyński T.: Effect of extending hot weather periods on approach to floor construction in moderate climate residential buildings. Civil and Environmental Engineering Reports 1, 20 (2016) 159-170.

31. Staszczuk A., Kuczyński T., Wojciech M., Ziembicki P.: Comparative calculation of heat exchange with the ground in residential building including periodes of heat waves, Civil and Environmental Engineering Reports 2, 21 (2016) 109-119.

32. Szewczyk J., Gientka D.: Terrestrial hest flow in Poland - a new approach. Geological Quarterly 53, 1 (2009) 125-140.

33. www.lubuskie.p1/news/16806/16/o-nowej-ustwie-OZE, access date: 27 March 2015.

34. www.stat.gov.pl., Bank Danych Lokalnych, access date: 02 November 2015.

35. www.stat.gov.pl., Statistical Yearbook 2013, access date: 02 November 2015.

36. www.stat.gov.pl., Agricultural Statistical Yearbook 2014, access date: 02 November 2015.

37. www.ure.gov.pl, Data from the Energy Regulatory Office for 31 December 2014., access date: 02 November 2015. 


\section{ODNAWIALNE ŹRÓDŁA ENERGII W WOJEWÓDZTWIE LUBUSKIM (POLSKA). STAN OBECNY I PERSPEKTYWY ROZWOJU}

\section{Streszczenie}

Artykuł prezentuje stan obecny produkcji energii ze źródeł odnawialnych oraz perspektywy jego rozwoju w oparciu o badania istniejących zasobów i możliwości ich wykorzystania. Województwo lubuskie nie jest znaczącym producentem energii elektrycznej w Polsce. Pod względem ilości produkcji energii zajmuje 12 miejsce na 16 województw. Roczna produkcja energii ze źródeł odnawialnych wynosi 290,9 GWh, co stanowi 11,6\% ogólnej produkcji. W województwie lubuskim na koniec 2014 roku były zainstalowane 73 koncesjonowane elektroenergetyczne źródła wytwórcze OZE o łącznej mocy 189 MW. Największą moc osiągamy z elektrowni wodnej szczytowopompowej (91,3 MW). Łączna moc koncesjonowanych instalacji wykorzystujących OZE w województwie lubuskim wzrosła ze $103 \mathrm{MW}$ w 2007 r. do około $189 \mathrm{MW}$ w 2014 roku. Badania istniejących zasobów wskazują na możliwość rozwoju OZE. Trwają przygotowania do budowy 66 nowych farm wiatrowych, o łącznej mocy 1834 MW [32], 89 elektrowni fotowoltaicznych o łącznej mocy $468 \mathrm{MW}, 21$ elektrowni wodnych o mocy ok. $60 \mathrm{MW}, 54$ elektrowni biogazowych obiektów o łącznej orientacyjnej mocy wynoszącej około $67 \mathrm{MW}$. Łączna moc planowanych do budowy instalacji OZE do 2023 roku ma wynieść 2469 MW. Najbliższe lata mają zatem przynieść aż 13-krotny wzrost zainstalowanej mocy instalacji OZE w województwie lubuskim. Nadal nie planuje się jedynie wykorzystanie geotermii głębokiej ze względu na niską opłacalność.

Słowa kluczowe odnawialne źródła energii OZE, Lubuskie

Editor received the manuscript: 27.022018 